\title{
Palynological evidence from a sub-alpine marsh of enhanced Little Ice Age snowpack in the Marrakech High Atlas, North Africa
}

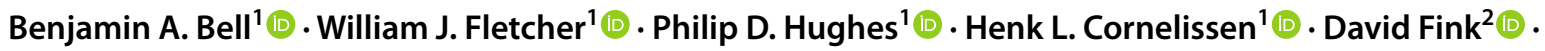 \\ Ali Rhoujjati ${ }^{3}$ (D)
}

Received: 31 July 2020 / Accepted: 16 April 2021 / Published online: 18 May 2021

(c) The Author(s) 2021

\begin{abstract}
The grazing lands of the High Atlas are vulnerable to climate change and the decline of traditional management practices. However, prior to the mid-20th century, there is little information to examine historical environmental change and resilience to past climate variability. Here, we present a new pollen, non-pollen palynomorph (NPP) and microcharcoal record from a sub-alpine marsh (pozzine) at Oukaïmeden, located in the Marrakech High Atlas, Morocco. The record reveals a history of grazing impacts with diverse non-arboreal pollen assemblages dominant throughout the record as well as recurrent shifts between wetter and drier conditions. A large suite of radiocarbon dates $(n=22)$ constrains the deposit to the last $\sim 1,000$ years although multiple reversed ages preclude development of a robust age-depth model for all intervals. Between relatively dry conditions during the Medieval period and in the 20th century, intervening wet conditions are observed, which we interpret as a locally enhanced snowpack during the Little Ice Age. Hydrological fluctuations evidenced by wetland pollen and NPPs are possibly associated with centennial-scale precipitation variability evidenced in regional speleothem records. The pollen record reveals an herbaceous grassland flora resilient against climatic fluctuations through the last millennium, possibly supported by sustainable collective management practices ( $a g d a l$ ), with grazing indicators suggesting a flourishing pastoral economy. However, during the 20th century, floristic changes and increases in charcoal accumulation point to a decline in management practices, diversification of land-use (including afforestation) and intensification of human activity.
\end{abstract}

Keywords Climate dynamics $\cdot$ Vegetation dynamics $\cdot$ Alpine ecology $\cdot$ Snow melt $\cdot$ Mountain environment $\cdot$ Pollen $\cdot$ Nonpollen palynomorphs

\section{Introduction}

High mountain environments are vulnerable to climate change impacts, especially in semi-arid settings where ris-

Communicated by J.-L. de Beaulieu.

Benjamin A. Bell

benjamin.bell@manchester.ac.uk

William J. Fletcher

will.fletcher@manchester.ac.uk

1 Quaternary Environments and Geoarchaeology (QEG), Department of Geography, School of Environment, Education and Development, The University of Manchester, Oxford Road, Manchester M13 9PL, UK

2 Australian Nuclear Science and Technology Organisation, PMB1, Menai, Sydney, NSW 2234, Australia

3 Faculté des Sciences et Techniques, Laboratoire Géoresources (URAC 42), Université Cadi Ayyad, Guéliz, BP 549, 40000 Marrakech, Morocco ing temperatures are compounded by climatic extremes and drought (Pepin et al. 2015; McCullough et al. 2016). In the Marrakech High Atlas of Morocco, pastoralism and transhumance are key strategies for exploiting the seasonal resources of the mountain environment. The upland pastures of Oukaïmeden, Tichka and Yagour represent areas of high floristic biodiversity and endemism as well as a cultural legacy, being deeply rooted in prehistory and maintained by cultural and religious practices regulating seasonal grazing access (Mahdi 2010). However, the pastoral landscapes and transhumant way of life are under threat from environmental and societal change. Insights from palaeoecology into the history of these landscapes can provide valuable context and understanding to support their conservation and protection. 
The dependence of the High Atlas pastures on snowmelt underlines their exposure to precipitation variability and particularly to snowpack (area and volume of snow cover) fluctuations (cf. Baba et al. 2018; Tuel et al. 2020). In this respect, they exemplify a key global change driver in the Mediterranean and Northwest Africa, specifically, declining precipitation with increased unpredictability and extremes (García-Ruiz et al. 2011). Snowmelt from the High Atlas is an important water resource for the neighbouring arid plains, contributing $\sim 40 \%$ of the annual hydrological budget today, underlining its status as the "water tower" (cf. Polo et al. 2020) of southern Morocco (Boudhar et al. 2010; Jarlan et al. 2015; Baba et al. 2018; Tuel et al. 2020). In the last century, a decline in the accumulation and/or preservation of winter snow has had economic implications (Diao et al. 2008), highlighting the significance of snowmelt for society in this region. While current observations and modelling highlight the sensitivity of the High Atlas snowpack to climatic change (Marchane et al. 2017), little is known about the state of the cryosphere in Northwest Africa during the Holocene. Documentary, observational and geomorphological evidence points to more extensive permanent snowfields and even niche glaciers during the Little Ice Age (Hughes 2014, 2018; Hannah et al. 2017; Hughes et al. 2020). However, the understanding of Holocene changes in snow and ice cover and resulting environmental impacts remains limited. As such, records of environmental change from snowmeltsensitive settings have a key role to play in elucidating the timing and impacts of past hydrological changes.

To date, only a small number of palaeoecological studies have been undertaken in the High Atlas. The undated pollen record of Tighislant (Bernard and Reille 1987), located $\sim 50 \mathrm{~km}$ to the northeast of Oukaïmeden, suggests that the High Atlas formerly supported a greater forest cover with Pinus and Quercus, and reveals a transition at an unknown age towards an open shrubland landscape with $C i s-$ tus and anthropogenic indicators (Cerealia, Juglans). Reille (1976) presented a pollen record from Oukaïmeden based on a $200 \mathrm{~cm}$ core of sedge peat overlying sands with a radiocarbon date of 2,680 \pm 50 BP at $150 \mathrm{~cm}$ depth (Reille 1976). The record is dominated by herbaceous pollen (Lactuceae, Plantago, Caryophyllaceae, Rumex, Cerealia) pointing to an open landscape with intense anthropogenic pressure. The record also shows fluctuating high abundances of Poaceae and Cyperaceae, although the palaeoclimatic significance was considered unclear. More recently, Ruiz Zabata et al. (2010) and Ruiz et al. (2014) reconstructed a 5,000-year history of vegetation dynamics at Oukaïmeden based on a composite of radiocarbon-dated cores and archaeological deposits showing fluctuating hydrological conditions over this period as anthropogenic activity including grazing and agrarian activity progressively increased. A largely open landscape with Asteraceae, Poaceae and Plantago prevailed, although Juniperus was found throughout the record, with more recent peaks in arboricultural taxa Olea (olive trees) and Juglans (walnut trees). These studies highlight the important potential for palaeoecological insights from the small wetlands of the High Atlas.

In this study, we present a new multiproxy palaeoecological record (pollen, non-pollen palynomorphs (NPPs) and microcharcoal) from a small terrestrial wetland on the Oukaïmeden plateau for the last $\sim 1,000$ years. The aim is to reconstruct past environmental changes at the site and explore human-environment interactions in the Oukaïmeden agdal, as well as the impact that snow melt has on the alpine ecology. We hypothesise that past snowpack extent was a key driver of hydrological changes on the Oukaïmeden plateau, and that resulting ecological changes influenced the pattern of human exploitation of the upland pastures.

\section{Study setting}

Oukaïmeden is a high elevation plateau $(\sim 2,600 \mathrm{~m}$ a.s.l. $)$ situated in a fault-aligned (ENE-WSW) depression on the north flank of the High Atlas, $80 \mathrm{~km}$ south of Marrakech (Fig. 1) formed on continental fluvial deposits of the Upper Triassic Oukaïmeden Sandstone formation (Benaouiss et al. 1996; Fabuel-Perez et al. 2009). The area is bounded to the south by Angour (3,616 m), one of the highest peaks of the High Atlas, whose northern slopes were glaciated in the late Pleistocene, evidenced by moraines present in valleys of Angour (Hughes et al. 2004, 2011, 2018). The Precambrian igneous rocks which form Jbel Oukaïmeden and Adrar n'Ouchattar are largely intrusive granites with extrusive andesite-basaltrhyolites towards the highest parts of the catchment, especially near Angour. Oukaïmeden village lies on the western side of the plateau, today, a popular ski resort during the snow season. The wet marshes and grasslands of this area are used for animal grazing, while small, terraced croplands can be found on the mountain slopes towards Ait el Qaq at lower elevations. A permanent lake (Lac Oukaïmeden) formed by the construction of a dam in the 1970s is located in the Assif n'Ait Irene valley, one of the upper headwaters of the Ourika valley. Ephemeral streams are active during periods of snow melt, flooding areas of low gradient forming localised marshes.

A sediment core (OUK1) was taken from a small marsh ('pozzine') located at $7^{\circ} 50^{\prime} 45.0^{\prime \prime} \mathrm{W}, 31^{\circ} 12^{\prime} 34.8 " \mathrm{~N}, \sim 2,600 \mathrm{~m}$ a.s.l. in the Assif Tiferguine valley to the east of Oukaïmeden village. The coring site is in a shallow valley at the boundary between Jurassic-Triassic sandstones and Precambrian granitic igneous lithologies derived from the upper mountain catchment. The marsh itself is sustained by snow melt from snowpack, which is often present for as much as six months of the year from November to late April/early May (Fig. 2a). 


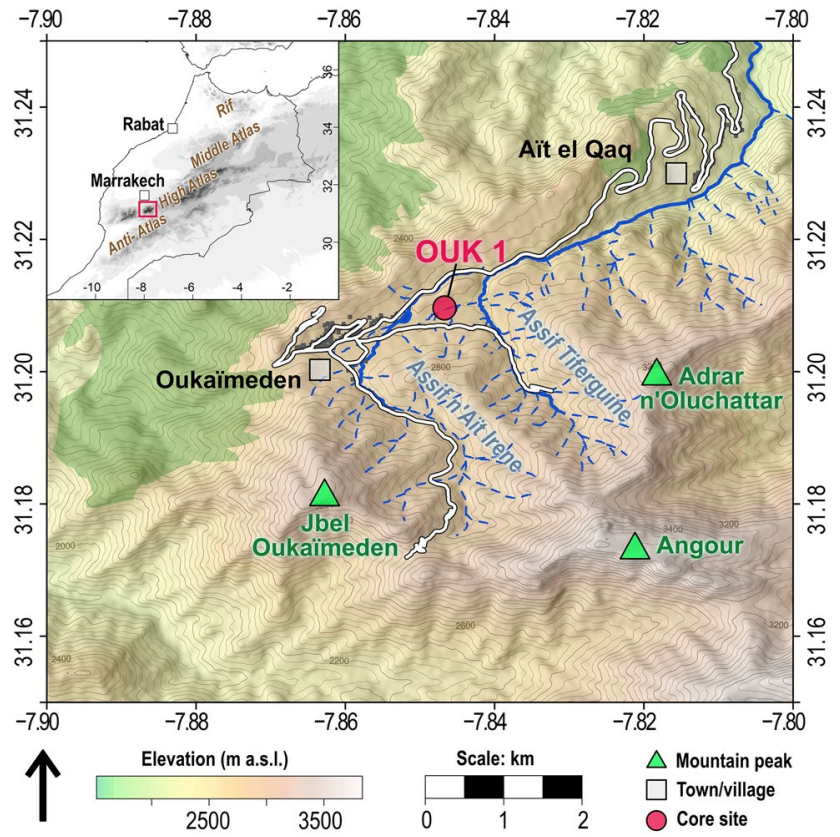

Fig. 1 Main map shows OUK 1 coring site on the Oukaïmeden plateau. Inset map shows study area within Morocco. Map based on ASTER GDEM v003 (NASA/METI/AIST/Japan Spacesystems 2019)

\section{Vegetation}

The High Atlas displays an altitudinal distribution of vegetation belts in common with mountain ranges of the Mediterranean basin (Ozenda 1975). Oukaïmeden is located near the upper limits of the Oro-Mediterranean stage characterised by arborescent juniper (Juniperus thurifera L.) and spiny xerophytes (Achhal et al. 1979; Benabid 1982). The High Atlas is distinguished by extreme degradation of its natural forest cover, a feature noted a century ago (Sorre 1924). The grassland flora of the Oukaïmeden plateau is very diverse (Fig. 2b), with more than 198 species and a very high degree of endemism (27\%) (Haroni et al. 2009). The closure of the agdal between March 15 and August 10 allows many plants to flower and set seed before the annual arrival of livestock (cattle, sheep and goats) (Haroni and Alifriqui 2012). The floristic diversity also relates to the presence of wetlands which develop in small depressions and on flat ground where sands, silts and humic material accumulate allowing the retention of precipitation and snowmelt. In the tradition of Corsican botany (Briquet 1910), these montane wetlands are known as pozzines. Four main grassland facies (highly wet, wet, fairly wet, dry) with corresponding differences in substrate, soil humidity, slope angle and vegetation cover (Gauquelin 1988) have been distinguished: (i) the pozzines and highly wet grasslands (HWG) with Nardus stricta L. and Carex intricata Tineo, (ii) wet grasslands (WG) with Ranunculus aurasiacus Pomel; (iii) fairly wet grasslands
(FWG) with Festuca maroccana (Trab.) Dobignard \& Portal; and (iv) dry grasslands (DG) with Astragalus ibrahimianus Maire (Haroni and Alifriqui 2012).

Local vegetation at the coring site corresponds to the WG facies with $R$. aurasiacus and Cyperaceae, subject to shallow flooding during snowmelt periods (Fig. 2a) and drier conditions during summer (Fig. 2b). In early summer, a rich meadow flora can be observed with Armeria atlantica Pomel, Trifolium arvense L., Helianthemum croceum (Desf.) Pers. and diverse Asteraceae spp. on the surrounding slopes, with ruderal elements especially near the shepherds' huts (Echium plantagineum L., Isatis tinctoria L., Paronychia argentea Lam., Malva sp.) as well as Polygonum bistorta L., Dactylorhiza elata (Poir.) Soó and Juncus sp. on damp and grassy stream banks (Fig. 2b). While the core site is largely devoid of arboreal cover, mixed conifer (Juniperus thurifera, Pinus halepensis Mill.) and broadleaf forest (Quercus rotundifolia Lam., Alnus, Fraxinus) are found on the slopes below $2,400 \mathrm{~m}$ a.s.l. to the north and the west of the core site, with some scattered individual juniper trees located to the south (e.g. Ruiz Zabata et al. 2010; DeSoto et al. 2014). There are also small plantations of Cedrus atlantica (Endl.) Manetti ex Carrière and pines to the north-east of the core site close to Ait el Qaq, and south of Jbel Oukaïmeden.

\section{Climate}

The climate of the High Atlas is highly seasonal, influenced by Atlantic air masses from the north-west during autumn and winter, and Saharan air masses from the south during late spring and summer months (Knippertz et al. 2003; Born et al. 2008; Fink et al. 2010). Mean annual temperature at Oukaïmeden is $9{ }^{\circ} \mathrm{C}$, with hot summers (average monthly maxima reaching $24{ }^{\circ} \mathrm{C}$ in July) and cold winters (average monthly minima of $-3{ }^{\circ} \mathrm{C}$ in January) (Badri et al. 1994; Simonneaux et al. 2008). Mean annual precipitation at Oukaïmeden was $540 \mathrm{~mm} / \mathrm{yr}$ for the period 1982-1994 (Badri et al. 1994) and $525 \mathrm{~mm} / \mathrm{yr}$ in 1989-2007 (Simonneaux et al. 2008) with the wettest months from January to April and a typical drought period (shaded area shown in Fig. 3a) extending from June to September (Badri et al. 1994). There is large year-to-year precipitation variability; for the period 1989-2007, total values (including rainfall and snowfall) ranged between less than $300 \mathrm{~mm}$ to nearly $900 \mathrm{~mm}$, corresponding to a coefficient of variation of annual precipitation $>30 \%$ (Simonneaux et al. 2008) (Fig. 3b). The pattern of very high inter-annual variation of precipitation is common across the High Atlas (Hughes et al. 2020). However, since the mountains are largely ungauged and have large altitudinal variability with significant proportions of precipitation falling as snow, the actual precipitation over high elevations remains challenging to determine with high accuracy (Tuel et al. 2020). 

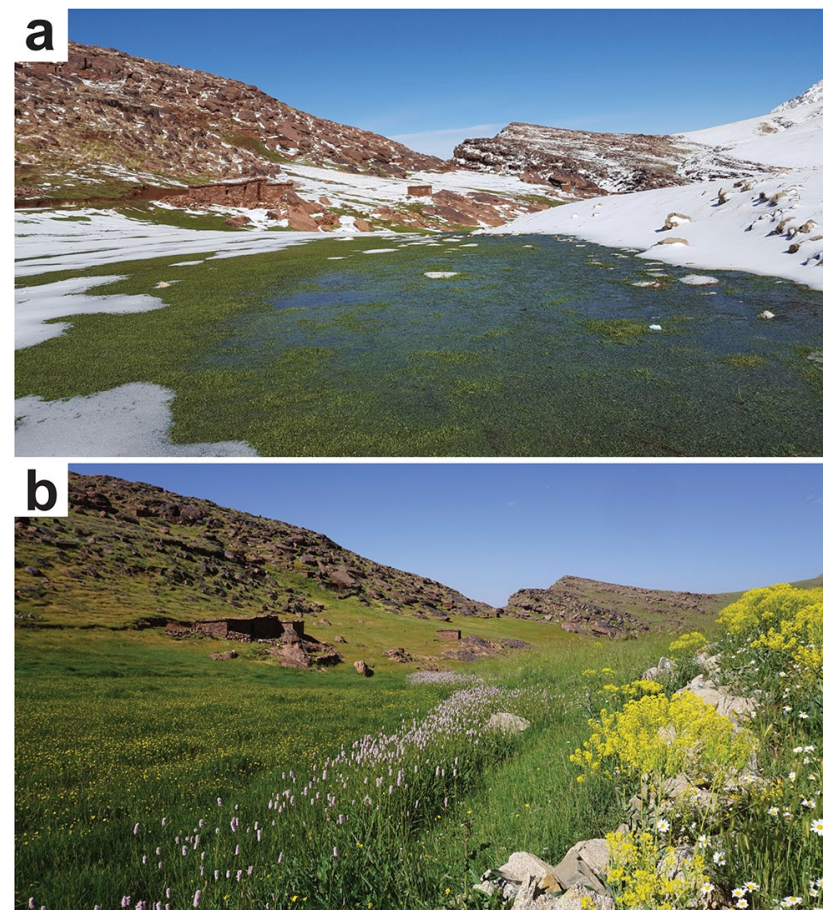

Fig. 2 Photographs showing the coring location: a Under a wet flush of snowmelt after late autumn snow (November, 2018), and b During early summer (June, 2019) showing the diverse flowering vegetation of the wetland-meadow transition (Ranunculaceae, Polygonaceae, Brassicaceae, Asteraceae, Poaceae etc.). Note the proximity to herders' seasonal huts (azibs), seen in the middle-ground. (Photographs: B. Bell)

Snow can survive for long periods on the higher mountain slopes, especially in the shaded north-facing gullies of Angour, lasting until June. A semi-permanent snowpatch has been reported at a similar altitude on the north face of the Tazaghart plateau to the southwest, sustained by avalanching snow into shaded north-facing gullies (Hughes 2014, 2018; Hannah et al. 2017). In fact, late-lying snow is observed at numerous sites across the High Atlas (Hughes et al. 2020). Snow is therefore a key control on the hydrology of the alpine zone in the High Atlas, buffering the drying effects of high temperatures, high insolation and low summer precipitation via snowmelt contribution. This is likely to have been greatly increased during cooler intervals of the Holocene, such as the Little Ice Age (Hughes 2014, 2018) significantly increasing the snowpack of these mountains compared with today (cf. Tuel et al. 2020). The location of the Oukaïmeden core site therefore provides an important opportunity to study past snowmelt in this region.

\section{Materials and methods}

\section{Core retrieval and sedimentological analysis}

Following prospection with a narrow gouge auger in May 2011, a $92 \mathrm{~cm}$ sediment core was recovered in 3 parts using a Russian corer from the wet marsh, wrapped in clingfilm, and kept in cold storage at $4{ }^{\circ} \mathrm{C}$ at The University of Manchester Geography laboratories. The top $4 \mathrm{~cm}$ of the core was not recovered due to the thickness of the rootmat. Organic content was determined by loss-on-ignition (LOI), with samples dried overnight at $105^{\circ} \mathrm{C}$ and fired at $550{ }^{\circ} \mathrm{C}$ for $3 \mathrm{~h}$ following Dean (1974). Magnetic susceptibility was determined using a Bartington MS2C core loop scanner following Dearing (1999). Lead concentration was determined on the uppermost core section using a handheld Themo Fisher Niton XRF analyser held for $2 \mathrm{~min}$ at $1 \mathrm{~cm}$ intervals for the top $50 \mathrm{~cm}$ of the core.

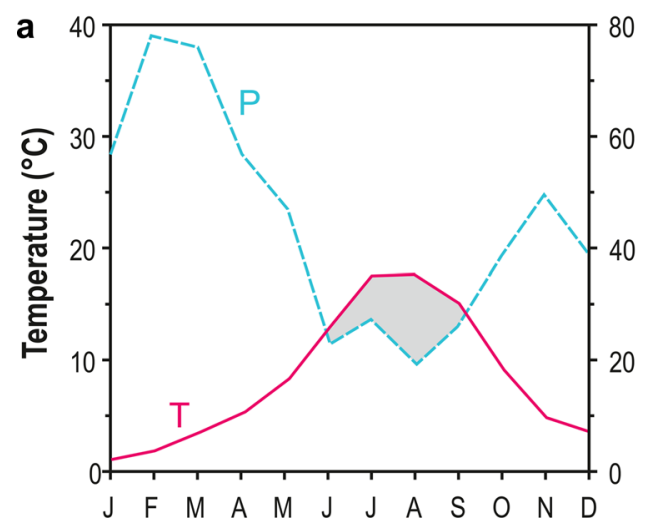

Fig. 3 Climate data from the Oukaïmeden station: a ombrothermic diagram for the period 1982-1994 showing average monthly temperature ( $\mathrm{T}$, red solid line), average monthly precipitation ( $\mathrm{P}$, blue dashed line) and summer drought period (shaded), redrawn from Badri et al.

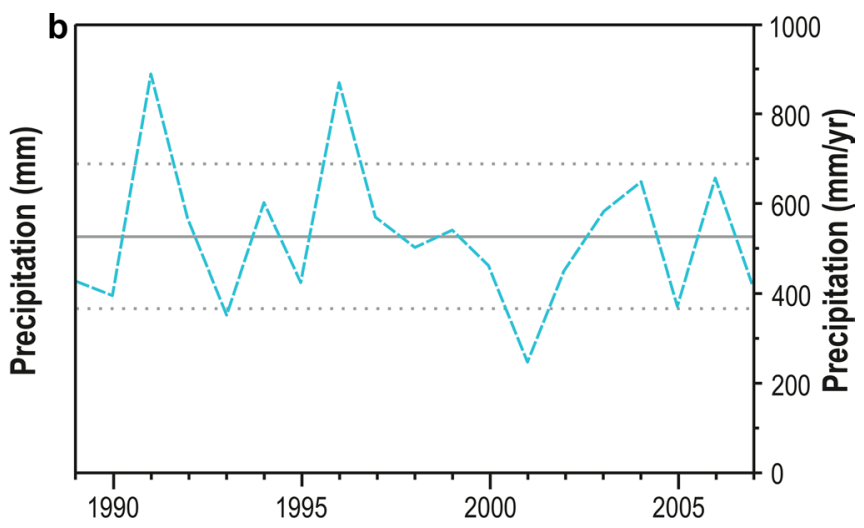

(1994) and b annual precipitation variability for the period 19892007 annotated with the mean (solid horizontal line) and 1 s.d. (dotted horizontal lines), redrawn from Simonneaux et al. (2008) 


\section{Organic microfossil analysis}

A total of 43 pollen samples were prepared from $1 \mathrm{~cm}^{3}$ subsamples every $2 \mathrm{~cm}$ using standard pollen preparation techniques including acetolysis (Erdtman 1960) and densemedia separation (Nakagawa et al. 1998; Campbell et al. 2016). Lycopodium marker tablets were added to each sample for absolute pollen analysis (Stockmarr 1971). Pollen and NPPs were identified under a high-power Zeiss binocular microscope at $400 \times$ and $1,000 \times$ magnification. Pollen grains were identified with reference to Beug (2004) and Reille (1992, 1995). Plantaginaceae were identified to standard types (Clarke and Jones 1977), while Plantago crassifolia was distinguished from P. coronopus by a larger diameter, increased number of pores and thicker annulus (Ubera et al. 1988; Al-Quran 2004). Non-pollen palynomorphs (NPPs) were identified according to Table 1 .

Average pollen counts (excluding wetland and NPPs) were 318 grains per sample excluding samples at $5 \mathrm{~cm}$, $7 \mathrm{~cm}, 11 \mathrm{~cm}$ and $39 \mathrm{~cm}$ depths which had an average count of 86 grains due to very low-concentration pollen residues. Main sum pollen percentages were calculated excluding wetland and NPPs. Wetland and NPP percentages were calculated using main sum plus individual taxa. The pollen diagram was created using the R package "rioja" v0.9-21 (Juggins 2017) with R v4.0.3 (R Core Team 2020). Pollen zonation was performed on main sum pollen taxa exceeding a threshold of $3 \%$ in at least one sample by the technique of optimal splitting by information content (Bennett 1996), selecting a significant number of zones as compared with a "broken-stick" model of random variance. Micro-charcoal concentrations were determined by counting 200 charcoal particles and Lycopodium grains following Finsinger and Tinner 2005.

\section{Ordination}

To examine the composition and structure of the main pollen dataset, we performed principal components analysis (PCA) on a selection of pollen taxa occurring at least once above a $3 \%$ threshold. While we recognise that taxa falling below this threshold may be ecologically significant, their detection at very low levels may be erratic or discontinuous and could thus lead to spurious associations in the ordination. Taxa that were likely to derive from long-distance transport or from lower elevations, such as Olea, Pinus and other arboreal taxa, were removed. Potentially ambiguous or duplicate taxa with low taxonomic resolution were also excluded when related taxa with higher taxonomic resolution were also recorded, e.g. Asteraceae indet. was removed since this might correspond to any of several more highly resolved taxa: Lactuceae, Aster-type, Anthemis-type etc. PCA was performed on the Hellinger transformed pollen data (Legendre and Gallagher 2001) with species scaling to unit variance. To evaluate the relationship between compositional changes in the grasslands pollen data and other proxies of environmental change (Wetland pollen abundances, NPP indicators (Wetland, Grazing, Fire, Erosion) and CHAR) we performed environmental (passive) fitting of these proxies onto the PCA ordination axes. Analysis was performed using the R package "vegan" v2.5-6 (Oksanen et al. 2017) with R v4.0.3 (R Core Team 2020).

Table 1 Non-pollen palynomorph identification, their indicative meaning and source material

\begin{tabular}{llll}
\hline Non-Pollen Palynomorph & Indicative meaning & Group & Source \\
\hline HdV-1 Gelasinospora-type & $\begin{array}{c}\text { Highly decomposed peat and charred plant } \\
\text { remains/Fire }\end{array}$ & Fire & van Geel and Aptroot (2006) \\
HdV-6 Coniochaeta & $\begin{array}{l}\text { Dung or decaying wood } \\
\text { Dung / grazing pressure }\end{array}$ & Grazing & Innes and Blackford (2003), Munk 1957 \\
HdV-55A/B Sordaria & Charred plant remains/Fire & Grazing & van Geel (1978) \\
HdV-55C Neurospora & Dung / grazing pressure & Fire & van Geel et al. (2017) \\
HdV-113 Sporormiella & Local presence of Carex species & Grazing & van Geel and Aptroot (2006) \\
HdV-126 Gaeumannomyces & Stagnant shallow water / lake margins & Wetland & Pals et al. (1980), van Geel (2001) \\
HdV-132 Spirogyra & Eutrophic to Mesotrophic conditions, soil & Soil erosion & van Geel (1976) \\
HdV-143 Diporotheca & disturbance & Geel et al. (1986) \\
HdV-182 & Stagnant shallow water & Wetland & Carrión and Navarro (2002), van Geel et al. \\
HdV-1047 Rhytidospora cf. tetraspora & Dung / grazing pressure & (1983) \\
HdV-1103 Glomus sp. & Soil erosion & Grazing & van Geel and Aptroot (2006) \\
Cladocera & Pools of surface water & Soil erosion & Anderson et al. (1984), Medeanic and Silva \\
& & Wetland & Frey (1960), van Geel (1978)
\end{tabular}




\section{Radiocarbon dating}

Radiocarbon dating was performed on 22 samples spaced throughout the core. Coarse plant material $(>180 \mu \mathrm{m})$ was screened from $1 \mathrm{~cm}^{3}$ core subsamples and received standard acid, alkali, acid treatment for ${ }^{14} \mathrm{C}$ AMS dating at the relevant laboratory. For samples with very low organic content, bulk sediment samples were used instead. An initial set of rangefinder dates suggested good potential to develop a wiggle-matched age-depth model (Blaauw et al. 2004) and supported the dating of additional samples to achieve a high density of radiocarbon dates. Unfortunately, due to many reversals (which we discuss in 'Problematic age model') this approach was ultimately not possible. Re-dating further samples was undertaken to test for errors or contamination but did not substantially change the pattern of ages. Bayesian age modelling was performed using the R package "rbacon" v2.5.0 (Blaauw et al. 2020) with R v4.0.3 (R Core Team 2020). The IntCal20 (Reimer et al. 2020) and Postbomb $\mathrm{NH} 2$ (Hua et al. 2013) calibration curves were used as necessary for older and younger ages, respectively.

\section{Results}

\section{Sedimentological analysis}

The OUK1 core consists of silty clays with variable organic matter content (predominantly coarse leaf tissue). An underlying unit of coarse sands was observed with a gouge auger extending more than $50 \mathrm{~cm}$ below the base of core, but this was loosely consolidated and not recoverable. The basal core section corresponding to $92-80 \mathrm{~cm}$ depth contains pale grey, clay-rich sediment with low organic content $(\mathrm{LOI}<10 \%)$ and relatively high magnetic susceptibility (Fig. 4). From $80 \mathrm{~cm}$ to the top of the core, brown organic-rich silts dominate, with high LOI (up to $50 \%$ ) corresponding to a peaty characteristic, and low magnetic susceptibility. This section contains three sandy bands of $1 \mathrm{~cm}$ thickness observed at $29-30 \mathrm{~cm}, 35-36 \mathrm{~cm}$ and $51-52 \mathrm{~cm}$ depths. Sand grains embedded within the organic-rich silty matrix at/near these depths reduces organic content. In the uppermost part of the core (above $16 \mathrm{~cm}$ depth), organic content decreases (LOI 25\%).

Lead concentration values are very low between 50 and $12 \mathrm{~cm}$ depth (values $<4 \mathrm{ppm}$ ), increase very slightly to $\sim 5 \mathrm{ppm}$ above $12 \mathrm{~cm}$, then increase substantially at the top of the core $(8-5 \mathrm{~cm}$ depth) reaching a peak value exceeding $100 \mathrm{ppm}$ at the top of the recovered sequence.

\section{Microfossil analysis}

Pollen was generally well preserved throughout the core with 77 distinct pollen types and 12 NPPs identified. Selected pollen and NPP assemblages are presented in Fig. 5. Nonarboreal pollen (NAP) dominates the sequence with an average of $95 \%$ NAP vs $5 \%$ arboreal pollen (AP) with high abundances of Poaceae, Asteraceae, Brassicaceae, Caryophyllaceae and Plantago-types (Fig. 5a). There are high, fluctuating abundances of wetland taxa (Fig. 5b), especially Cyperaceae and Juncaceae, which show affinities for fluctuations in NPPs indicative of wet conditions, notably HdV-126 Gaeumannomyces, Spirogyra and Cladocera). Coprophilous fungal NPPs (notably HdV-55A/B Sordaria and HdV-113 Sporormiella) are recorded at some depths. Fire indicators (Gelasinospora, Neurospora and microcharcoal) are also detected. Based on the main sum taxa, three significant pollen assemblage zones are distinguished, for which the key features are summarised in Table 2. Full pollen data are available in the ESM.

\section{Ordination}

There are two significant axes in the PCA as determined by a broken-stick model of the variance, explaining a cumulative $48.1 \%$ of the variance in the grassland pollen dataset. Principal component (PC) 1 captures differences in composition between samples of zones OUK1-I, OUK1-II and OUK1-III, with strong positive loadings for Lactuceae, Anthemis-type and Caryophyllaceae and negative loadings for Plantago crassifolia and P. albicans-types, Aspleniaceae, Cirsium and Poaceae (Fig. 6). NPP erosion indicators (primarily Glomus) are significantly correlated with PC1, while Juncaceae pollen abundance and charcoal are negatively correlated. PC2 primarily discriminates between samples of OUK1-II from the under- and over-lying zones, with strong positive loadings for Plantago coronopus and Genista- as well as Lotustypes, and negative loading for Helianthemum. Abundances of Cyperaceae pollen and wetland NPPs are significantly correlated with PC2.

\section{Chronology}

The results of the radiocarbon dating on 22 samples from core OUK1 are presented in Table 3. The three bulk-sediment dates from the lower clay-rich unit yielded a coherent series of ages with increasing age with depth approximating to the long-term mean sedimentation rates for the core. These dates confirm that the core represents at least $\sim 1,000$ years. In contrast, multiple reversals are present in the dataset for the overlying organic-rich unit $(80-5 \mathrm{~cm})$. The issues surrounding the age model and chronology are further explored under 'Problematic age model'. 
Fig. 4 Sedimentological data for OUK1 core, showing depths of ${ }^{14} \mathrm{C}$ and pollen samples, visual stratigraphy and notes on composition, organic content, magnetic susceptibility (reversed axis), and lead (Pb) concentration

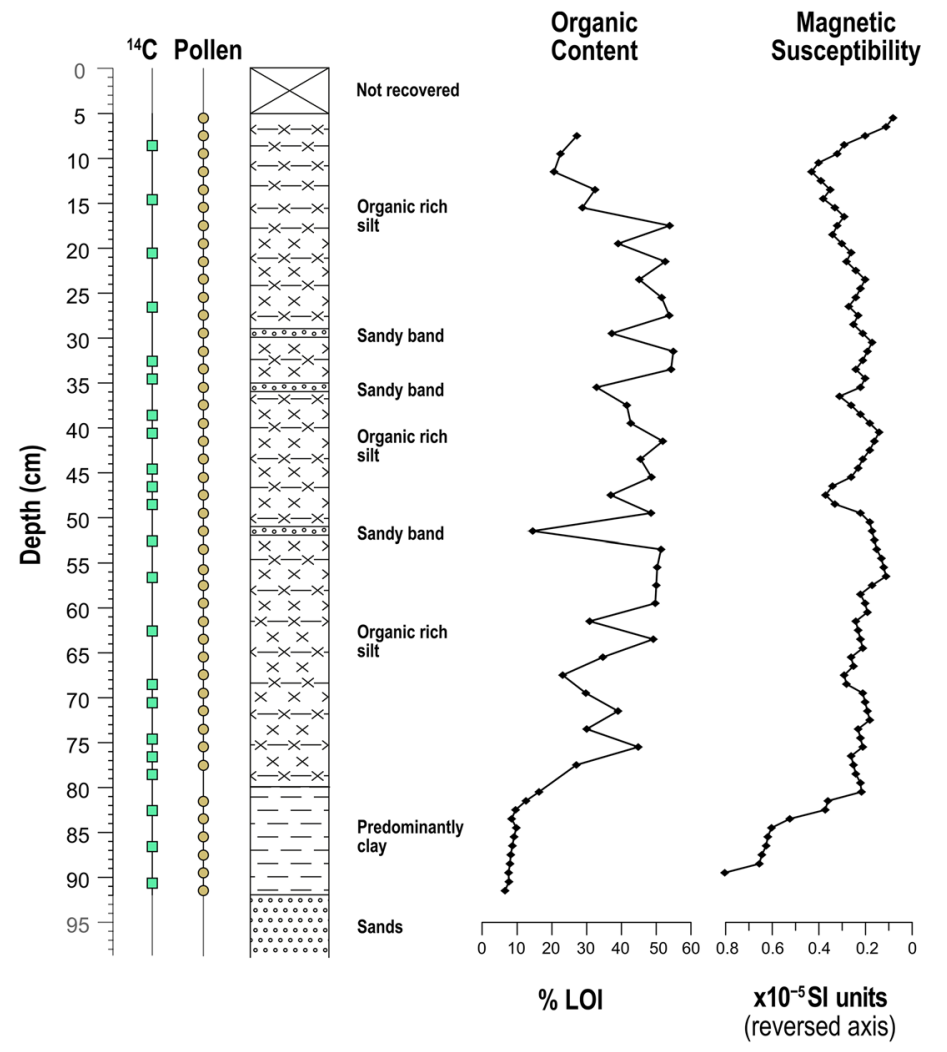

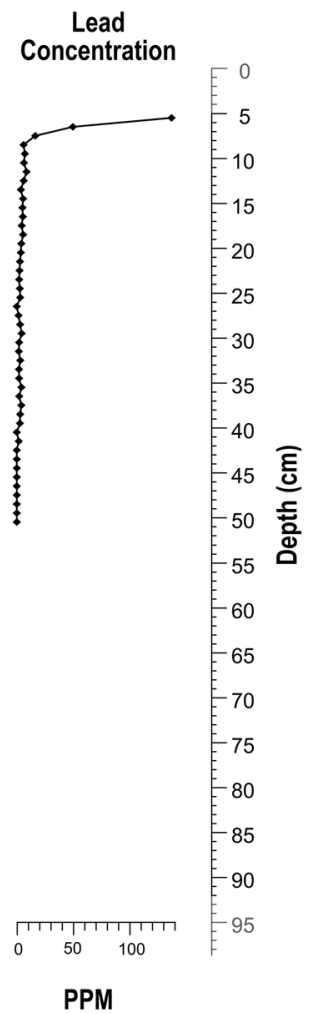

\section{Discussion}

\section{Problematic age model}

For the Oukaïmeden core, the aim was to generate a highly resolved age model to complement the high-resolution pollen analysis and permit robust comparison with Moroccan speleothem and tree-ring records (e.g. Esper et al. 2007; Wassenburg et al. 2013). While the initial range finder dates returned promising results, additional dating of samples returned multiple age reversals with many apparent postbomb dates throughout the core. Bayesian age modelling (Fig. 7.) was performed using various settings, with and without a hiatus, and by varying the inclusion or exclusion of some dates (outliers). However, most models produced an age-depth curve that would suggest an unrealistically young upper deposit, with the top $50 \mathrm{~cm}$ of sediment representing only a 100-year period (1904-2011). This would imply extremely high (virtually instantaneous) accumulation rates, which do not appear realistic considering the well-defined core stratigraphy (Fig. 4). This includes the preservation of three laterally continuous discrete sandy layers, which does not evidence of slumping or mass movements.

Some complexities were anticipated due to large fluctuations in the calibration curve for recent centuries (resulting from major fluctuations in solar activity and hence radiocarbon production in the atmosphere, as well as impacts of nuclear activity in the 20th century). However, while the modern ages appear to be the most obvious candidates for contamination and thus removed from the model, inconsistencies with some other dates suggest further contamination is present to varying degrees. The most problematic dates appear in the middle section of the core, which is characterised by high organic content and dominated by wetland taxa, notably Cyperaceae species for which the local presence is supported by the presence of HdV-126 Gaeumannomyces, a fungal pathogen of Cyperaceae rootstocks. Conversely, the top and bottom segments of the core have low levels of organic matter and the lowest concentration of Cyperaceae and reveal plausible ages. In addition to inferred reliable dates near the base of the core $(92-80 \mathrm{~cm})$, the uppermost date at the very top of the core also appears reliable, corresponding to peak $\mathrm{Pb}$ concentrations and tree plantation (Cedrus) in the late 20th century. Furthermore, Oukaïmeden village underwent significant development during the mid20th century, which could account for some of the rapid sedimentation suggested by the age model at the top of the core.

We suspect that the occurrence of modern ages at multiple depths within the central core section results from downward penetration of fine rootlets of vascular plants into the organic-rich sediments. Although large rootlets were removed with tweezers in the preparation of the samples for dating, rootlets too fine to be removed and detritus from 

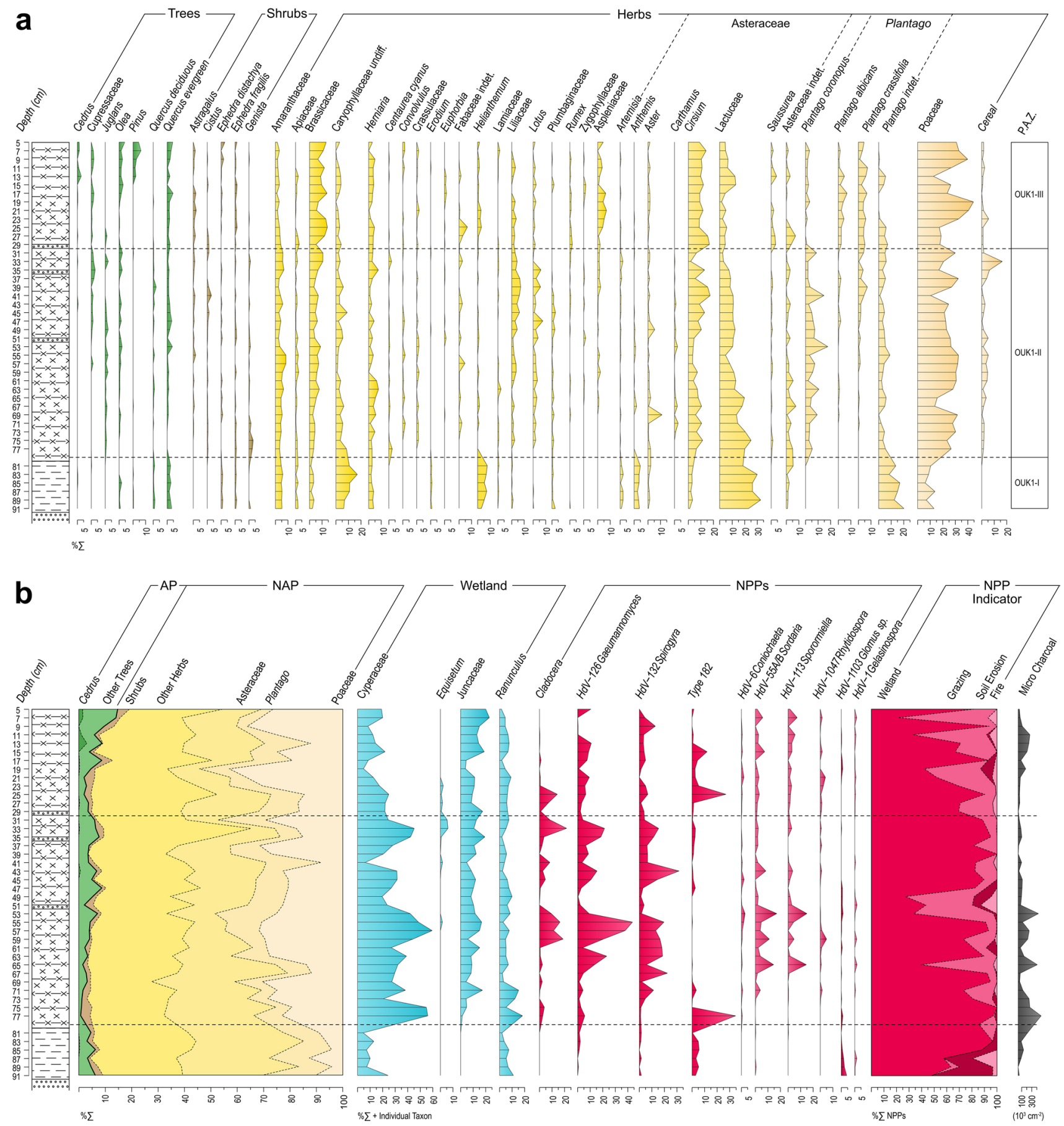

Fig. 5 Pollen diagram showing select pollen types, NPPs, and microcharcoal data from Oukaïmeden plotted against core depth (cm)

partially decomposed rootlets may have been present. It is known that sedge roots can penetrate deeply (up to $2 \mathrm{~m}$ ) into peat (Saarinen 1996), even if the bulk of root matter is typically concentrated near the surface. In one boreal peatland study, typical sedge rooting depths in a $1 \mathrm{~m}$ peat deposit overlying clay ranged from $30 \mathrm{~cm}$ on wetter sites to $56 \mathrm{~cm}$ on drained sites (Strack et al. 2006). The shallow overall depth of the OUK1 deposit and hydric stresses of the climate regime could favour deep root penetration into the organic-rich deposit. The build-up of intrusive fine rootlets may therefore be responsible for a "rejuvenation effect" in the dated humin fraction (acid and alkali insoluble detritus), which may be exacerbated by lateral export of soluble humic acids derived from decomposition of leaf litter (Shore et al. 1995). Unexpectedly young ages in the order of centuries or more have been previously reported in sedge peats 
Table 2 Summary of trends within pollen assemblage zones (PAZs) for OUK1 core

\begin{tabular}{|c|c|c|}
\hline PAZ & Depth $(\mathrm{cm})$ & Main features \\
\hline OUK1-III & $30-5$ & $\begin{array}{l}\text { - Highest abundance of Poaceae and corresponding low abundance of Cyperaceae } \\
\text { - Increase in Juncaceae, overtaking Cyperaceae as the dominant wetland taxa } \\
\text { - Highest overall abundance of arboreal taxa, particularly Cedrus, Cupressaceae, Olea, Pinus and Quercus evergreen } \\
\text { - Highest abundances of Brassicaceae and Aspleniaceae, with notable reductions in Liliaceae and Lotus pollen } \\
\text { - Cirsium continues its increasing trend, and Lactuceae has a small resurgence } \\
\text { - All types of Plantago are common, particularly P. albicans and P. crassifolia types } \\
\text { - Reduction in wetland NPPs, with increased periods dominated by grazing indicators }\end{array}$ \\
\hline OUK1-II & $80-30$ & $\begin{array}{l}\text { - Most "extreme" peaks and troughs of Cyperaceae throughout this zone, also evidenced by largest corresponding } \\
\text { peaks of HdV-126 } \\
\text { - Poaceae peaks and troughs less pronounced compared to Cyperaceae } \\
\text { - Increasing abundance of Lactuceae towards the bottom of the core, the reverse trend is evident for Cirsium } \\
\text { - Plantago coronopus is the dominant type. No P. albicans or P. crassifolia at the lower core depths } \\
\text { - Almost no Cedrus and Pinus, while Juglans is common throughout (relative to other AP) } \\
\text { - High abundance of NPPs, dominated by wetland indicators, with two high grazing periods }\end{array}$ \\
\hline OUK1-I & $92-80$ & $\begin{array}{l}\text { - Low abundance of both Cyperaceae and Poaceae compared to other zones } \\
\text { - Highest abundance of Lactuceae, with less variety in Asteraceae types } \\
\text { - Highest abundance of Helianthemum and Caryophyllaceae } \\
\text { - Arboreal dominated by Quercus } \\
\text { - NPPs indicate less of a wetland environment at the bottom of the zone, but greater soil disturbance }\end{array}$ \\
\hline
\end{tabular}

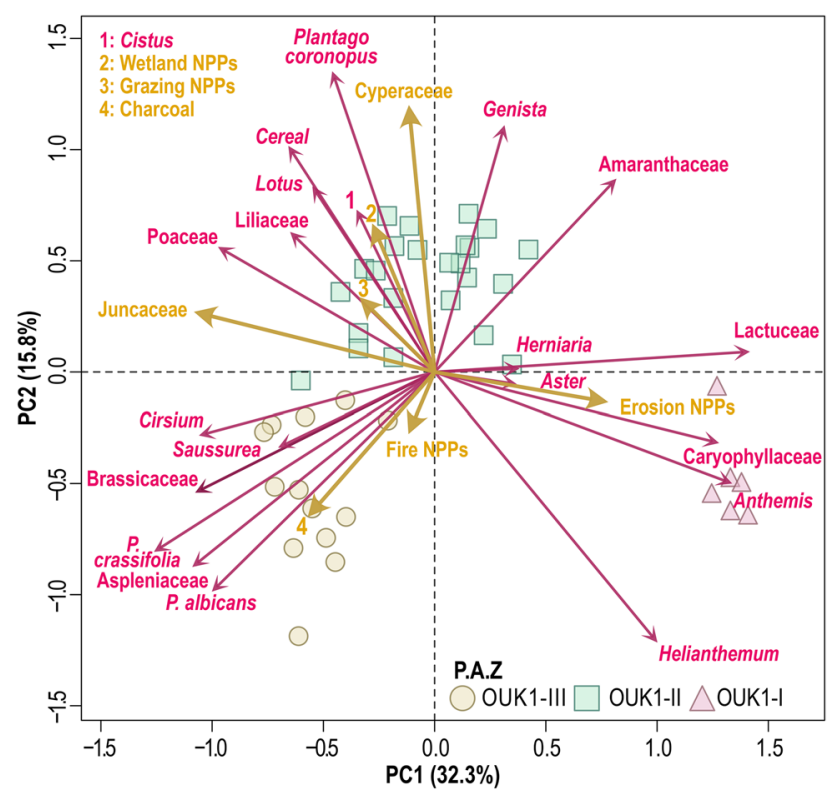

Fig. 6 PCA biplot for the grassland pollen dataset, first and second ordination axes. Species vectors (pollen taxa) shown with red arrows. Environmental (passive) fitting of wetland pollen and NPP groups is shown with gold arrows

from temperate and high-latitude settings (Head et al. 2007; Väliranta et al. 2014). Similar problems may be occurring in the OUK case due to a combination of highly seasonal moisture regime and topogenous setting leading to sub-surface lateral groundwater flow through the deposit (promoting both mobility of humic acids as well as creating an attractive moisture reservoir for deeper rooting plants). Certainly, the problem of rootlet intrusion from overlying sediment will also be most critical in a sub-recent deposit due to the extremely high ${ }^{14} \mathrm{C}$ content of plant matter which formed in the second half of the 20th century, since the percentage of modern carbon (pMC) averaged $140 \mathrm{pMC}$ over this interval and peaked at $>190 \mathrm{pMC}$ in the 1960s. Modest contributions of intrusive rootlets ( $<20 \%$ of the sample) could therefore result in apparent modern ages for samples of $\sim 1,000$ years age where $89 \mathrm{pMC}$ is anticipated (Väliranta et al. 2014); this appears the most likely explanation for reported values near $100 \mathrm{pMC}$ at $68-69 \mathrm{~cm}, 52-53 \mathrm{~cm}, 40-41 \mathrm{~cm}, 38-39 \mathrm{~cm}$, $34-35 \mathrm{~cm}, 32-33 \mathrm{~cm}$ and $26-27 \mathrm{~cm}$ depth (Table 3 ), all occurring within the rooting zone depth range of mid- to late 20 th century plants. Similarly, high pMC values $20-21 \mathrm{~cm}$ and $14-15 \mathrm{~cm}$ depth may also reflect enrichment in ${ }^{14} \mathrm{C}$ of the dense upper root mat zone of plants which grew in the aftermath of 20th century bomb-testing (Hua et al. 2013). Overall, these problems appear confined to the peaty layer without affecting the underlying clay deposit.

In addition to root penetration, trampling by grazing animals cannot be ruled out as a mechanism for downward movement of plant matter within the stratigraphy. However, we did not observe sedimentary structures indicating bioturbation and we draw attention especially to lateral continuity of the stratigraphy observed at the site when taking the core, including preservation of thin sand layers, which are inconsistent with mixing processes, as well as a nonhomogenised microfossil content revealing stratigraphically 
Table 3 Full radiocarbon data for OUK1 core

\begin{tabular}{|c|c|c|c|c|c|c|}
\hline Depth (cm) & Lab. $\operatorname{code}^{\mathrm{a}}$ & Material & $\%$ modern carbon $(\mathrm{pMC})^{\mathrm{b}}$ & ${ }^{14} \mathrm{C}$ age (BP) & cal. age, $2 \sigma(\mathrm{AD})^{\mathrm{c}}$ & $\delta^{13} \mathrm{C}(\% o)$ \\
\hline $8-9$ & OxA-38383 & Plant remains & $110.24 \pm 0.33$ & Modern & $1957-2001$ & -28.5 \\
\hline $14-15$ & OxA-38384 & Plant remains & $134.00 \pm 0.35$ & Modern & $1962-1979$ & -28.1 \\
\hline $20-21$ & OxA-38385 & Plant remains & $123.65 \pm 0.35$ & Modern & 1959-1985 & -29.2 \\
\hline $26-27$ & OxA-38386 & Plant remains & $101.32 \pm 0.31$ & Modern & $1955-1956$ & -28.8 \\
\hline $32-33$ & OxA-38387 & Plant remains & $102.70 \pm 0.32$ & Modern & $1956-1956$ & -28.2 \\
\hline $34-35$ & OxA-41083 & Plant remains & $101.30 \pm 0.35$ & Modern & $1955-1956$ & -29.1 \\
\hline $38-39$ & OxA-38388 & Plant remains & $101.45 \pm 0.30$ & Modern & $1955-1956$ & -29.0 \\
\hline $40-41$ & OxA-41084 & Plant remains & $100.79 \pm 0.29$ & Modern & $1955-1955$ & -28.2 \\
\hline $44-45$ & OxA-38389 & Plant remains & $108.79 \pm 0.31$ & Modern & 1957-2002 & -27.5 \\
\hline $46-47$ & OxA-41085 & Plant remains & $98.55 \pm 0.33$ & $117 \pm 27$ & $1683-1938$ & -28.0 \\
\hline $48-49$ & Beta-383073 & Plant remains & $98.52 \pm 0.37$ & $120 \pm 30$ & $1680-1940$ & -28.2 \\
\hline $52-53$ & OxA-38390 & Plant remains & $102.18 \pm 0.28$ & Modern & 1956-1956 & -27.6 \\
\hline $56-57$ & OxA-38391 & Plant remains & $99.52 \pm 0.28$ & $39 \pm 23$ & $1697-1918$ & -27.7 \\
\hline $62-63$ & OxA-38392 & Plant remains & $97.41 \pm 0.33$ & $211 \pm 27$ & $1646-1950$ & -28.0 \\
\hline $68-69$ & OxA-38393 & Plant remains & $101.00 \pm 0.30$ & Modern & 1955-1956 & -27.6 \\
\hline $70-71$ & OxA-41086 & Plant remains & $94.06 \pm 0.32$ & $492 \pm 27$ & $1407-1447$ & -28.1 \\
\hline $74-75$ & OxA-38394 & Plant remains & $89.05 \pm 0.32$ & $932 \pm 29$ & $1033-1198$ & -29.6 \\
\hline $76-77$ & OxA-41087 & Plant remains & $95.78 \pm 0.32$ & $346 \pm 27$ & $1472-1636$ & -28.7 \\
\hline $78-79$ & Beta-386066 & Plant remains & $95.86 \pm 0.36$ & $340 \pm 30$ & $1476-1638$ & -26.7 \\
\hline $82-83$ & OZY-316 & Bulk sediment & $89.62 \pm 0.33$ & $880 \pm 30$ & $1046-1221$ & -27.2 \\
\hline $86-87$ & OZY-315 & Bulk sediment & $88.85 \pm 0.28$ & $950 \pm 25$ & $1032-1157$ & -26.6 \\
\hline $90-91$ & OZY-314 & Bulk sediment & $88.30 \pm 0.27$ & $1,000 \pm 25$ & $994-1150$ & -26.2 \\
\hline
\end{tabular}

${ }^{\mathrm{a}} O x A$ Oxford radiocarbon accelerator unit, Beta Beta analytic, $O Z Y$ ANSTO

b pMC values calculated using the "clam" package (Blaauw 2010) with R v4.0.3 (R Core Team 2020)

${ }^{\mathrm{c}}$ Negative conventional radiocarbon ages (Modern) derived from the Bomb $13 \mathrm{NH} 2$ calibration curve and result in ages $>1950$ AD, other positive conventional ages $(<1950 \mathrm{AD})$ used the IntCal20 calibration curve

distinct assemblages. Ultimately, further palaeoecological studies for this time interval in the High Atlas are required to resolve fully the questions raised by the complex ${ }^{14} \mathrm{C}$ dataset, ideally including a range of site types and dating methods to cross-check and circumvent the challenges highlighted in this work.

In light of these considerations, we present an idealised age model (Fig. 7, red dashed curve) alongside the Bayesian age model, reflecting a simple monotonic curve constrained only by the three lowermost ages from the inorganic deposit and the core top age. We suggest that this may represent a likely age-depth profile for the deposit and that the generally consistent direction but noisy amplitude of young-shifted age offsets from this idealised model reflects a variable degree of fine rootlet contamination. Overall, a typical discrepancy in the order of 100-200 years may be noted between the (young-shifted) Bayesian and idealised age model (Fig. 7). In a typical radiocarbon-dated Holocene sequence, constrained by an average density of ages of 1-2 dates per millennium (Lacourse and Gajewski 2020) such errors would most likely not be detectable. Nevertheless, the noisy radiocarbon dataset unfortunately precludes development of the intended high-precision age model, revealing instead noteworthy challenges for future dating of shallow, sub-recent peat deposits in the High Atlas. These may potentially be addressed by careful experimentation with dating of different materials, including pollen concentrates (e.g. Fletcher et al. 2017). Ultimately, despite these problems, the dating approach constrains the total deposit robustly to the last $\sim 1,000$ years. The basal clay deposit corresponding to pollen zone OUK1-I is also constrained with good confidence to the 11th to 13th centuries AD (mean modelled ages, AD 1000-1280). This upper age is significant as it represents a terminus post quem for the transition to wetter conditions reflected in the overlying sediment composition and palaeoecological indicators.

\section{Environmental history of Oukaïmeden during the last millennium}

\section{Formation and infilling of the pozzine}

The studied OUK1 deposit accumulated during the last millennium, with two distinct phases of sediment accumulation. 
Fig. 7 Annotated age model for the OUK1 core, presenting the Bayesian age-depth model (mean age is shown as a thick gold line, with $95 \%$ confidence bands shown within the dotted grey lines). The age model shown here was generated using all available radiocarbon data with rbacon using default settings. An idealised age model is shown as a red dashed line. Green highlighting indicates depths with high confidence in the age model. Select sedimentological information shown for comparison, with lead values (dark grey line), organic content (purple line) and sand layers (yellow symbols and highlighting)

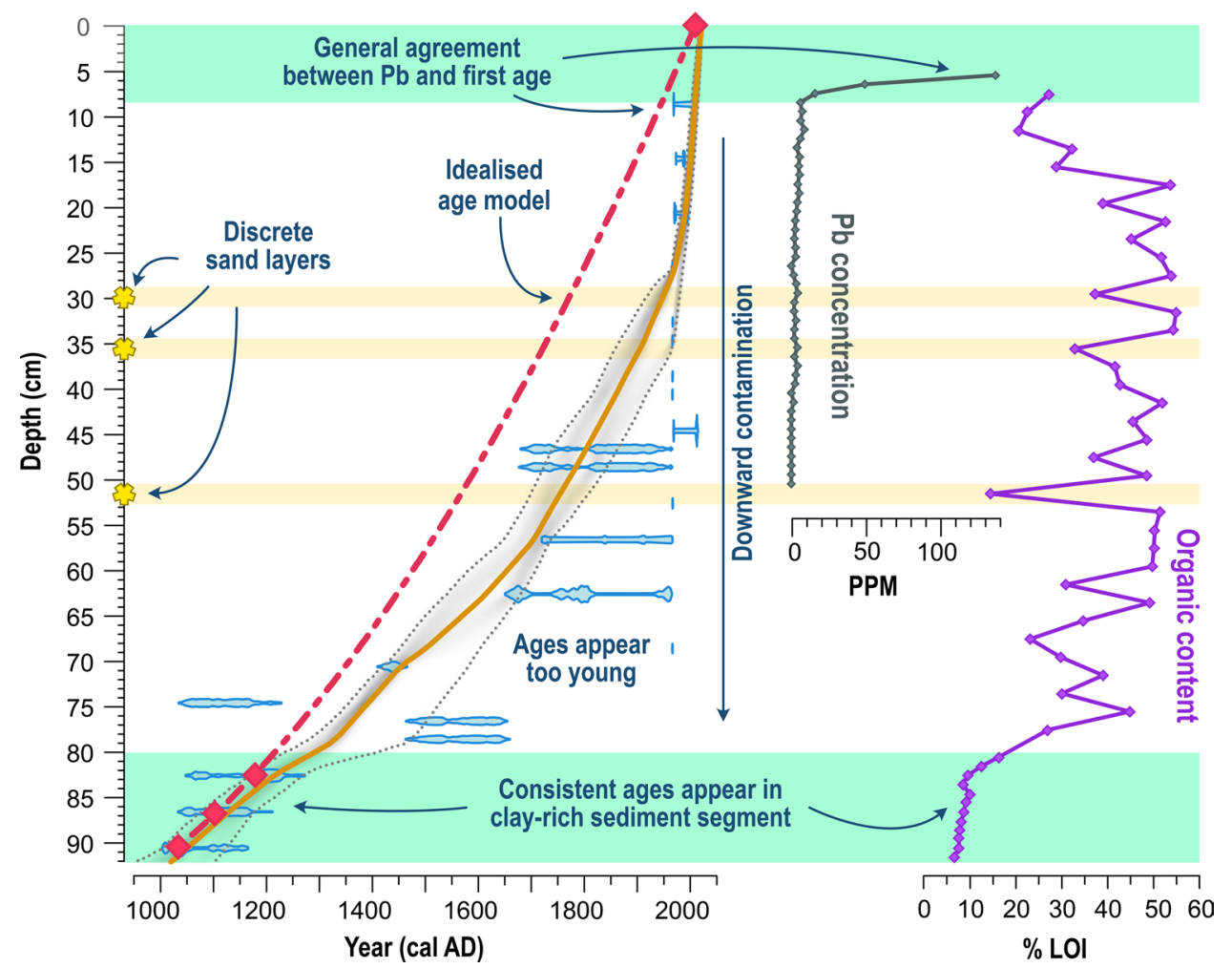

The first is characterised by high clay and low organic content and is dated with good confidence to AD 1000-1280. This phase thus occurred within the Medieval Climate Anomaly (MCA) (Moberg et al. 2005). The second is characterised by high organic content with abundant plant macrofossils; although there is less certainty about the age, it commenced after around $\mathrm{AD} 1250$ and persisted through the coolest centuries of the Little Ice Age (Moberg et al. 2005). The underlying sand deposit beneath the OUK1 core suggests an arid and/or high-energy hydrological regime prevailed, possibly associated with flashy or torrential streamflow through the site. While it is possible that the transition to fine-grained sedimentation was occasioned by internal dynamics in the local stream system, for example, initiation of ponding by the installation of a natural barrier to streamflow by rockfall or soil creep, the most likely scenario might be a shift from drier to wetter prevailing climate, with more sustained and predictable water supply to the site. An increase in precipitation after AD 650-850 over SW Morocco has been inferred from terrigenous sediment and pollen in marine core GeoB8601-3 off Cape Ghir in southwestern Morocco (Zhao et al. 2019), although a complex interplay of anthropogenic and climatic drivers is recognised (cf. McGregor et al. 2009). As the Oukaïmeden wetlands are primarily maintained by snowmelt (Haroni and Alifriqui 2012), this change may have been caused by an increase in snowmelt supply from the north-facing mountain slopes via overland runoff and spring-fed contribution. Across the
Oukaïmeden area, pollen-bearing deposits of greater antiquity are known (Reille 1976; Ruiz et al. 2014), so the formation of the OUK1 pozzine is not representative of the entire wetland complex. Rather, it reflects one element in a constantly evolving pattern of wetland extent and distribution that is highly sensitive to climatic changes (Haroni et al. 2009; Ruiz et al. 2014).

Three sandy bands are documented in the stratigraphy of core OUK1, occurring within, and at the upper boundary of, pollen zone OUK1-II. These centimetric-scale deposits are interpreted as markers of high-intensity overland runoff episodes. These episodes are likely to have been caused by torrential downpours in late summer to early autumn. Late summer season thunderstorms are a characteristic feature of the regional Atlas mountain climate (Knippertz et al. 2003) and intense localised downpours can lead to flash flooding and significant overland flows. Flooding from the highest catchments also occurs in springtime due to rainfall on snowpack (Zkhiri et al. 2017). However, the mobilisation of sands in the local area of the OUK1 pozzine at high elevation may be more likely to occur in the snow-free season, i.e. late summer to autumn.

\section{Pollen zone OUK1-I}

The lowermost pollen zone presents a low abundance of wetland taxa (pollen and NPPs). This zone corresponds to fine-grained sediments that are low in organic matter content 
$(<10 \%$ LOI) (Fig. 4). This suggests the site did not yet support a dense vegetated meadow and may have been prone to seasonal drying - comparable to the FWG facies and supported by inference from summertime field observations of small, dry depressions containing fine-grained deposits on the Oukaïmeden red sandstone plateau. High abundances of Helianthemum pollen may reflect $H$. croceum ssp. suffruticosum, a characteristic species of the FWG facies today (Haroni et al. 2009). Although not highly discriminatory, Caryophyllaceae and Lactuceae species are also well represented in the FWG to DG grassland settings (Haroni et al. 2009). Minor but distinctive abundances of Ephedra distachya, Erodium, Artemisia and Anthemis-type also point towards rather arid conditions on the surrounding slopes beyond the site, while peak abundances of Glomus and high magnetic susceptibility values indicate a contribution from unstable soils during this interval. In the absence of coarsegrained sediments in this unit, this soil contribution might be dust-borne as well as derived from slope erosion. This is similar to findings from the nearby Arroumd Valley in the Toubkal Massif of a Late Holocene sediment infill associated with early pastoral activity in these mountains (Fletcher and Hughes 2016).

\section{Pollen zone OUK1-II}

The zone shows a marked increase in taxa of the HWG and WG facies (Cyperaceae, Ranunuculaceae, Juncaceae) as well as wetland NPPs including Cladocera (water flea) fragments and aquatic algae (Spirogyra). High abundances of HdV-126 Gaeumannomyces hyphopodia, which develop directly on the epidermis of sedges, provide good confirmation of the local development of Cyperaceae at the site and establishment of the permanent vegetated surface of the pozzine (Pals et al. 1980). The prevailing change towards wetter conditions in the local setting is further evidenced by the major increase in organic matter content in the deposit and high preservation of leaf tissues yielding a near peaty character (up to $40 \%$ LOI), reflecting both local vegetative productivity and enhanced preservation conditions. High abundances of Poaceae in this zone point to the general development of a rich grassy meadow. Other taxa most likely associated with the slightly drier margins of the site (typical of the FWG facies) include Plantago coronopus- and Lotus-type. A very distinctive feature of OUK1-II is the high variability in the wetland pollen and NPP indicators, suggesting considerable fluctuations in moisture supply.

In conjunction with prevailing wetter local conditions at the core site, noteworthy changes in the composition of the surrounding flora are recorded. A subtle shift in shrub taxa is observed with increases in leguminous taxa (Genista- and Astragalus-type, also Fabaceae indet.). Cultivated plants are documented with the increase in Cereal pollen and
Juglans. The latter is well-represented in this zone, certainly derived from the arboriculture zones which are typical of this region along the irrigated stream margins near villages. NPP grazing indicators (principally Sordaria and Sporormiella) increase in this zone. OUK1-II also shows a rise in Cirsium pollen along with Saussurea and Carthamus-type, further suggesting the presence of heavily grazed patches with nitrogen-enrichment. Cistus also increases, which in association with an increase in microcharcoal may suggest a modest fire response in patches of the nearby landscape, further supported by occasional but consistent observations of fungal spores of charred material (Gelasinospora and Neurospora) (cf. Fletcher and Hughes 2016). The proximity to the seasonal herder huts (azibs, Fig. 2) highlights a likely contribution from human activity to the burning signal.

\section{Pollen zone OUK1-III}

The uppermost pollen zone supports a progressive shift towards drier conditions evidenced by decreases in Cyperaceae and wetland NPPs (especially Cladocera, Spirogyra and HdV-126) in conjunction with declining organic matter content. A renewed increase in HdV-182 is detected, supporting a return to drier conditions inferred lower in the core (OUK1-I). Overall, the main wetland NPPs suggest differential abundance along a gradient from wettest (Cladocera) to driest (HdV-182) conditions (Fig. 5b) related to the depth and/or seasonal duration of standing water in the pozzine. In contrast to Cyperaceae, Juncaceae abundances are sustained and increase slightly, which may reflect the proliferation of this less palatable taxon under selective grazing (Steinman et al. 2003; Marty 2005; Bohlen and Gathumbi 2007; Tweel and Bohlen 2008), especially by cattle that preferentially graze the wettest pasturelands at Oukaïmeden (Haroni and Alifriqui 2012). The increase may also partly reflect the expansion of Juncus bufonius L. around the margins of the nearby dammed water body since the 1970s (Haroni et al. 2009). The uppermost pollen zone is distinguished by peak Poaceae abundances, high levels of Cirsium and Saussurea-type, and increase in Plantago albicans- and $P$. crassifolia-type. These indicators point to continued grazing pressure, supported by sustained albeit lower abundances of NPP grazing indicators. The increase in P. albicans- at the expense of $P$. coronopus-type suggests a relative increase in more arid-tolerant plantains typical of pastoral grazing lands in North Africa (Puech et al. 1998). Peak values of Brassicaceae and Rumex suggest an increase in ruderal taxa on disturbed ground (Jury et al. 2008). Distinctive increases in Pinus and Cedrus are almost certainly associated with recent plantations of these conifers on mountain slopes of the adjacent upper Ourika and Rheraya valleys. Microcharcoal concentrations are high, most likely reflecting human activity in the nearby azibs and Oukaïmeden village. While 
the overall composition of grassland taxa in OUK1-III is similar to OUK1-II as reflected by clustering in the PCA biplot (Fig. 6), some similarities with OUK1-I are observed, related especially to increased Helianthemum, pointing to an influence of drier prevailing conditions. Increased magnetic susceptibility and increased sedimentation rates further support the combined inference of drier conditions and increased disturbance. Peak values of Aspleniaceae reflect the flourishing of several Asplenium spp. in shady crevices on the local sandstone (Jury et al. 2008). The significance of Aspleniaceae in this zone is not certain but may represent a secondary succession on walls and rockpiles of the traditional azibs due to their reduced use since the era of motorized transport.

\section{Snowpack dynamics in the High Atlas}

As noted already 60 years ago (Quézel 1957), a remarkable stratigraphic feature of the High Atlas pozzines is the near-ubiquitous presence at depth of a layer of fossil sedge peat. Its presence beneath areas currently dominated by mat grass prairie (Nardeto-Festucetum community) points to a sub-recent period of much wetter conditions and subsequent aridification. Overall, our study confirms this observation at the OUK1 pozzine, and helps to constrain this interval of wetter conditions to the northern hemisphere Little Ice Age, contrasting with drier conditions during the Medieval Climate Anomaly and during the 20th century.

The restriction of Cyperaceae to the wettest pozzines, as noted by Quézel (1957) and supported by the detailed floristic study of Haroni et al. (2009), means that it should be a sensitive moisture proxy in this setting. Considering the near-subtropical latitude, high summer temperatures and low, unpredictable summer rainfall, sustained edaphic humidity at Oukaïmeden permitting the development of Cyperaceae must be supported by snowmelt. As such, fluctuations in wetland pollen abundance should be strongly influenced by snow and ice extent at high elevations. High snowfall during the winter and the subsequent spring and summer snow melt creates waterlogged conditions on the plateau supporting the development of wetland taxa. Conversely, low winter snowfall results in less snowmelt, resulting in drier conditions and floristic shifts in the pozzines. Similar dynamics have been reported in Wyoming, USA, where snow melt from late lying snow would form Cyperaceae bogs, whereas a lack of snow led to the formation of Poaceae dominated meadows (Johnson and Billings 1962; Billings and Mooney 1968).

Within the longer-term dry-wet-dry pattern of the last millennium, the Oukaïmeden wetland taxa reveal highamplitude short-term fluctuations, although age-model uncertainties preclude accurate age determination for the timing of individual events. However, comparison between the recent speleothem winter precipitation proxy from Ifoulki Cave in the SW High Atlas (Ait Brahim et al. 2017) and the wetland vegetation record from Oukaïmeden suggests a common mechanism to explain the similar dynamics. Specifically, wintertime precipitation increases as reflected in the speleothem geochemistry fed changes in snowpack accumulation in the highest mountain areas which in turn: (a) led to enhanced snowmelt supply to moisture-sensitive alpine grasslands, as at Oukaïmeden and (b) contributed to increased fluvial discharge to the Moroccan Atlantic margin, impacting on terrigenous sediment content of marine cores (e.g. Kuhlmann et al. 2004; McGregor et al. 2009; Zhao et al. 2019). The parallel dynamics across these proxies support a key role for hydrological fluctuations all consistent with the status of the High Atlas as the "water tower" of SW Morocco (Boudhar et al. 2009). The robustly dated speleothem record reveals a quasi-cyclical pattern to precipitation changes, with a $\sim 200 \mathrm{yr}$ periodic component which has been attributed to solar forcing of the regional hydroclimate (Ait Brahim et al. 2017, 2018). In particular, the deep solar minima of the Little Ice Age (Wolf, Spörer, Maunder and Dalton) appear associated with wetter conditions, possibly due to solar modulation of the strength and phase of the NAO (Ineson et al. 2011; Swingedouw et al. 2011; Thiéblemont et al. 2015), which in its negative phase is highly influential in steering the moisture-bearing wintertime westerlies towards Morocco. It is conceivable that an imprint of this $\sim 200 \mathrm{yr}$ cyclicity in synoptic-scale climatology is detected in the fluctuating wetland vegetation at Oukaïmeden.

The indirect evidence from wetland proxies for significantly enhanced year-round snowpack in the recent past is consistent with climatic, topographical and historical insights suggesting that present day conditions are close to a climatic threshold permitting year-to-year snow and ice accumulation in the highest cirques of the High Atlas (Hughes 2014, 2018; Hannah et al. 2017; Vieira et al. 2017; Hughes et al. 2020). The findings encourage further consideration of the Little Ice Age concept in the High Atlas setting. Overall, the prevailing paradigm in Morocco and the Western Mediterranean more widely is of a dry MCA and a wet Little Ice Age (Moreno et al. 2012; Fletcher and Zielhofer 2013; Lüning et al. 2017, 2019). This paradigm is supported by many Moroccan records, notably speleothems, lake-levels and tree-rings in the Middle Atlas (Esper et al. 2007; Détriché et al. 2009; Wassenburg et al. 2013), and is broadly consistent with long term changes observed at Oukaïmeden.

\section{Human-environment interactions}

The dominance of herbaceous vegetation types including nitrophilous and ruderal taxa portrays an anthropic 
open landscape at Oukaïmeden throughout at least the last 1,000 years, consistent with the longer pollen records of Ruiz Zabata et al. (2010) and Reille (1976). For the Medieval interval in the record (OUK1-I), high levels of soil erosion indicators and lower diversity of the grassland flora point to a somewhat degraded and unstable vegetation cover impacted by progressive climatic aridification.

The OUK1-II interval has high abundances of Poaceae (up to 40\%) and Fabaceae (especially Lotus-type) pollen, which may be particularly revealing about management of grazing access to the plateau. These families represent the richest grazing fodder, their nutritious seeds particularly being high in protein and prized by grazing animals (Haroni and Alifriqui 2012). Their abundance as part of a diverse suite of grassland taxa in OUK1-II does not support a scenario of unlimited grazing access since many taxa would therefore not reach flowering stage. The timing of grazing restrictions at Oukaïmeden and late opening (mid-August) of the grazing season permits the latest flowering taxa to set seed and underpins the biodiversity of the grasslands (Haroni and Alifriqui 2012). Although impossible to determine with certainty, the combination of high grazing NPPs and diverse pollen assemblages rich in Poaceae pollen suggest that the agdal may have been in operation already for many centuries, consistent with historical insights that extend the origins of the agdal to the early 16th century at least (Ilahiane 1999; Nieto 2015). At the same time, the records of Juglans and Cerealia convey a picture of thriving village agriculture and arboriculture in the nearby valleys. The grassland flora appears quite stable overall during this interval (OUK1-II). Therefore, despite the strongly anthropogenic characteristic of the flora, the diversity and stability of the grassland assemblage points to the prevailing sustainability of management practices and a resilient ecosystem. This equilibrium was most likely supported by higher water availability in the context of a generally greater-than-present snowpack supplying meltwater to the Oukaïmeden plateau.

Significant changes in the grassland flora are evident in OUK1-III, likely to represent the late 19th and 20th centuries. These changes correspond to a period of major political and social changes in Morocco commencing during the colonial period. The French protectorate in Morocco was established in AD 1912 and progressively extended its influence into rural Morocco over subsequent decades. In 1949 the French Protectorate declared all pastureland to be of public use, overriding the agdal system that had operated in Oukaïmeden (Nieto 2015). Immediately following this decree, Oukaïmeden was developed into a ski resort, where a new permanent road, settlements, hotels, shops and restaurants were built (Bokbot and Ruiz-Gálvez 2014; Nieto 2015). This diversification of activities may be reflected in the increases in ruderal taxa and microcharcoal in the pozzine, while a continued grazing pressure is evidenced by sustained coprophilous fungal indicators. The signal of nearby Cedrus and Pinus plantations as well as a rise in more distant Olea groves testifies to landscape transformation with loss of grazing lands and an increase in arboriculture. As such, the OUK1 pozzine contains signals of the distinctive juxtaposition of tradition and modernity that characterises Oukaïmeden today (Nieto 2015). Progressive aridification of the pozzine matches the well-documented decline in winter precipitation during the second half of the 20th century and may ultimately threaten the wetland status of the pozzine in a drier and warmer 21 st century.

\section{Conclusions}

The new OUK1 pollen and NPP record provides insights into past environmental conditions and snowpack dynamics in the Marrakech High Atlas during the last 1,000 years. The pollen record reveals an open pastureland landscape throughout the last millennium, rich in floristic and fungal grazing indicators. The bottom section of the core, corresponding with the warmest centuries of the Medieval Climate Anomaly, indicates prevailing dry conditions, while wetter conditions observed in the middle section of the core likely prevailed during the Little Ice Age. The importance of snowmelt suggests significant changes in snowpack, with maximum snow and ice during the Little Ice Age, while high-amplitude, short-term fluctuations in wetland taxa reflect variability in wetland status. This pattern may be associated with changes in prevailing wintertime atmospheric circulation (NAO negative phase) with enhanced precipitation and snowpack accumulation. Overall, cooler and wetter conditions supported grazing activities on the Oukaïmeden plateau. In turn, the distinctive sustainable practices regulating access to the pasturelands (agdal) may explain the prevailing resilience of the herbaceous grassland flora to hydroclimatic fluctuations. Recent climatic aridification and diversification of human activities at Oukaïmeden are registered in the record and highlight the exposure of the High Atlas to climatic and societal change since the 20th century. Future palaeoecological investigations in the Marrakech High Atlas are needed to test the hypotheses developed in this work regarding climate-cryosphere-environment interactions and their implications for society, ideally drawing on a range of palaeoenvironmental archives and dating approaches to circumvent difficulties arising from radiocarbon dating in the pozzine setting.

Supplementary Information The online version contains supplementary material available at https://doi.org/10.1007/s00334-021-00837-y. 
Acknowledgements This work was funded by a SED (now SEED) Research Stimulation Fund award, a Natural Environment Research Council (NERC) radiocarbon award (allocation \#1858.1014), Australian Nuclear Science and Technology Organisation (ANSTO) dating support (portal \#11599), and a Leverhulme Trust research project (RPG-2018-141). We thank Sarah Kneen for assistance in the field, and John Moore, Tom Bishop and Jonathan Yarwood (University of Manchester) for laboratory assistance. We also thank Thomas Higham, David Chivall and Richard Staff (Oxford Radiocarbon Accelerator Unit) and Geraldine Jacobsen (ANSTO) for assistance with ${ }^{14} \mathrm{C}$ dating. We are grateful to two anonymous reviewers whose comments helped us to improve the manuscript.

Open Access This article is licensed under a Creative Commons Attribution 4.0 International License, which permits use, sharing, adaptation, distribution and reproduction in any medium or format, as long as you give appropriate credit to the original author(s) and the source, provide a link to the Creative Commons licence, and indicate if changes were made. The images or other third party material in this article are included in the article's Creative Commons licence, unless indicated otherwise in a credit line to the material. If material is not included in the article's Creative Commons licence and your intended use is not permitted by statutory regulation or exceeds the permitted use, you will need to obtain permission directly from the copyright holder. To view a copy of this licence, visit http://creativecommons.org/licenses/by/4.0/.

\section{References}

Achhal A, Akabli O, Barbero M et al (1979) À propos de la valeur bioclimatique et dynamique de quelques essences forestières au Maroc. Ecol Mediterr 5:211-249. https://doi.org/10.3406/ecmed. 1979.960

Ait Brahim Y, Cheng H, Sifeddine A et al (2017) Speleothem records decadal to multidecadal hydroclimate variations in southwestern Morocco during the last millennium. Earth Planet Sci Lett 476:1-10. https://doi.org/10.1016/j.eps1.2017.07.045

Ait Brahim Y, Wassenburg JA, Cruz FW et al (2018) Multi-decadal to centennial hydro-climate variability and linkage to solar forcing in the Western Mediterranean during the last 1,000 years. Sci Rep 8:17,446. https://doi.org/10.1038/s41598-018-35498-x

Al-Quran SA (2004) Pollen morphology of Plantaginaceae in Jordan. Pak J Biol Sci 7:1,594-1,602

Anderson RS, Homola RL, Davis RB, Jacobson GL (1984) Fossil remains of the mycorrhizal fungal Glomus fasciculatum complex in postglacial lake sediments from Maine. Can J Bot 62:2,3252,328. https://doi.org/https://doi.org/10.1139/b84-316

Baba MW, Gascoin S, Hanich L (2018) Assimilation of Sentinel-2 data into a snowpack model in the High Atlas of Morocco. Remote Sens 10:1982. https://doi.org/10.3390/rs10121982

Badri W, Gauquelin T, Minet J, Savoie JM (1994) Données météorologiques nouvelles sur le massif de l'Oukaïmeden (2570 m, Haut Atlas de Marrakech, Maroc): un exemple de climat de haute montagne méditerranéenne. Publ Assoc Int Climatol 7:190-198

Benabid A (1982) Bref aperçu sur la zonation altitudinale de la végétation climatique du Maroc. Ecol Mediterr 8:301-315

Benaouiss N, Courel L, Beauchamp J (1996) Rift-controlled fluvial/ tidal transitional series in the Oukaïmeden Sandstones, High Atlas of Marrakesh (Morocco). Sediment Geol 107:21-36. https://doi.org/10.1016/S0037-0738(96)00013-9
Bennett KD (1996) Determination of the number of zones in a biostratigraphical sequence. New Phytol 132:155-170. https://doi.org/10. 1111/j.1469-8137.1996.tb04521.x

Bernard J, Reille M (1987) Nouvelles analyses polliniques dans l'Atlas de Marrakech, Maroc. Pollen Spores 29:225-240

Beug HJ (2004) Leitfaden der Pollenbestimmung für Mitteleuropa und angrenzende Gebiete. Pfeil, München

Billings WD, Mooney HA (1968) The ecology of arctic and alpine plants. Biol Rev 43:481-529. https://doi.org/10.1111/j.1469185X.1968.tb00968.x

Blaauw M (2010) Methods and code for 'classical' age-modelling of radiocarbon sequences. Quat Geochronol 5:512-518

Blaauw M, van Geel B, Mauquoy D, van der Plicht J (2004) Carbon-14 wiggle-match dating of peat deposits: advantages and limitations. J Quat Sci 19:177-181. https://doi.org/10.1002/jqs.810

Blaauw M, Christen JA, Aquino Lopez et al (2020) Rbacon: age-depth modelling using Bayesian statistics. https://CRAN.R-project.org/ package $=$ rbacon

Bohlen PJ, Gathumbi SM (2007) Nitrogen cycling in seasonal wetlands in subtropical cattle pastures. Soil Sci Soc Am J 71:1,058-1,065. https://doi.org/10.2136/sssaj2005.00217

Bokbot Y, Ruiz-Gálvez M (2014) Art, landscape and settlement in the Oukaïmeden valley (High Atlas). A research project. Complutum 25:19-24. https://doi.org/10.5209/rev-CMPL.2014.v25.47337

Born K, Piecha K, Fink A (2008) Shifting climate zones in the Northwestern Maghreb. In: Schulz O, Judex M (eds) IMPETUS Atlas Morocco: research results 2000-2007, 3rd edn. Department of Geography, University of Bonn, Germany, pp 13-14

Boudhar A, Hanich L, Boulet G, Duchemin B, Berjamy B, Chehbouni A (2009) Evaluation of the Snowmelt Runoff Model in the Moroccan High Atlas Mountains using two snow-cover estimates. Hydrol Sci J 54:1094-1113. https://doi.org/10.1623/ hysj.54.6.1094

Boudhar A, Duchemin B, Hanich L et al (2010) Long-term analysis of snow-covered area in the Moroccan High-Atlas through remote sensing. Int J Appl Earth Obs Geoinf 12(Suppl 1):S109-S115. https://doi.org/10.1016/j.jag.2009.09.008

Briquet J (1910) Prodrome de la flore corse, comprenant les résultats botaniques de six voyages exécutés en Corse sous les auspices de M. Émile Burn 1. Edité par Georg \& Cie, Genève - Bale

Campbell JFE, Fletcher WJ, Hughes PD, Shuttleworth EL (2016) A comparison of pollen extraction methods confirms dense-media separation as a reliable method of pollen preparation. J Quat Sci 31:631-640. https://doi.org/10.1002/jqs.2886

Carrión JS, Navarro C (2002) Cryptogam spores and other non-pollen microfossils as sources of palaeoecological information: casestudies from Spain. Ann Bot Fenn 39:1-14

Clarke GCS, Jones MR (1977) The Northwest European Pollen Flora, Vol 15: Plantaginaceae. Rev Palaeobot Palynol 24:129-154

Dean WE (1974) Determination of carbonate and organic matter in calcareous sediments and sedimentary rocks by loss on ignition: comparison with other methods. J Sediment Res 44:242-248

Dearing J (1999) Magnetic susceptibility, environmental magnetism: a practical guide. QRA, London

DeSoto L, Varino F, Andrade JP, Gouveia CM, Campelo F, Trigo RM, Nabais C (2014) Different growth sensitivity to climate of the conifer Juniperus thurifera on both sides of the Mediterranean Sea. Int J Biometerol 58(10):2,095-2,109

Détriché S, Bréhéret JG, Soulié-Märsche I, Karrat L, Macaire JJ (2009) Late Holocene water level fluctuations of Lake Afourgagh (Middle-Atlas Mountains, Morocco) inferred from charophyte remains. Palaeogeogr Palaeoclimatol Palaeoecol 283:134-147. https://doi.org/10.1016/j.palaeo.2009.09.012

Diao X, Dinar A, Roe T, Tsur Y (2008) A general equilibrium analysis of conjunctive ground and surface water use with an application 
to Morocco. Agric Econ 38:117-135. https://doi.org/10.1111/j. 1574-0862.2008.00287.x

Erdtman G (1960) The acetolysis method: a revised description. Sven Bot Tidsk 54:561-564

Esper J, Frank D, Büntgen U, Verstege A, Luterbacher J, Xoplaki E (2007) Long-term drought severity variations in Morocco. Geophys Res Lett 34:L17702. https://doi.org/10.1029/2007GL0308 44

Fabuel-Perez I, Redfern J, Hodgetts D (2009) Sedimentology of an intra-montane rift-controlled fluvial dominated succession: the Upper Triassic Oukaïmeden Sandstone Formation, Central High Atlas, Morocco. Sediment Geol 218:103-140. https://doi.org/10. 1016/j.sedgeo.2009.04.006

Fink AH, Christoph M, Born K et al (2010) Climate. In: Speth P, Christoph M, Diekkruger B (eds) Impacts of global change on the hydrological cycle in West and Northwest Africa. Springer, Heidelberg, pp 54-58

Finsinger W, Tinner W (2005) Minimum count sums for charcoal concentration estimates in pollen slides: accuracy and potential errors. Holocene 15:293-297. https://doi.org/10.1191/09596 83605hl808rr

Fletcher WJ, Zielhofer C (2013) Fragility of Western Mediterranean landscapes during Holocene Rapid Climate Changes. CATENA 103:16-29. https://doi.org/10.1016/j.catena.2011.05.001

Fletcher WJ, Hughes PD (2016) Anthropogenic trigger for Late Holocene soil erosion in the Jebel Toubkal, High Atlas, Morocco. CATENA 149:713-726. https://doi.org/10.1016/j.catena.2016. 03.025

Fletcher WJ, Zielhofer C, Mischke S, Bryant C, Xu X, Fink D (2017) AMS radiocarbon dating of pollen concentrates in a karstic lake system. Quat Geochronol 39:112-123. https://doi.org/10.1016/j. quageo.2017.02.006

Frey DG (1960) The ecological significance of cladoceran remains in lake sediments. Ecology 41:684-699. https://doi.org/10.2307/ 1931802

García-Ruiz JM, López-Moreno II, Vicente-Serrano SM, LasantaMartínez T, Beguerí S (2011) Mediterranean water resources in a global change scenario. Earth-Science Rev 105:121-139. https://doi.org/10.1016/j.earscirev.2011.01.006

Gauquelin T (1988) Dynamique de la végétation et des formations superficielles dans les montagnes du bassin occidental de la Méditerranée: Etude des formations à genévrier thurifère et à xérophytes épineuses en coussinet des Atlas marocains. Universite Paul Sabatie, Toulouse

Hannah G, Hughes PD, Gibbard PL (2017) Pleistocene plateau ice fields in the High Atlas, Morocco. In: Hughes PD, Woodward JC (eds) Quaternary glaciation in the Mediterranean mountains. Geological Society, Special Publications, London 433. The Geological Society, London, pp 25-53. https://doi.org/10.1144/ SP433.12

Haroni SA, Alifriqui M (2012) Approche écologique des pâturages humides d'altitude et pratiques de gestion. Le plateau d'Oukaïmeden dans le Haut Atlas de Marrakech. In: Auclair L, Alifriqui M (eds) Agdal: Patrimoine socio-écologique de l'Atlas marocain. IRCAM-IRD, Rabat, pp 75-92

Haroni SA, Alifriqui M, Simonneaux V (2009) Recent dynamics of the wet pastures at Oukaïmeden plateau (High Atlas mountains, Morroco). Biodivers Conserv 18:167-189. https://doi.org/10. 1007/s10531-008-9465-6

Head K, Turney CSM, Pilcher JR, Palmer JG, Baillie MGL (2007) Problems with identifying the '8200-year cold event' in terrestrial records of the Atlantic seaboard: a case study from Dooagh, Achill Island, Ireland. J Quat Sci 22:65-75

Hua Q, Barbetti M, Rakowski AZ (2013) Atmospheric radiocarbon for the period 1950-2010. Radiocarbon 55:2,059-2,072. https://doi. org/10.2458/azu_js_rc.v55i2.16177
Hughes PD (2014) Little Ice Age glaciers in the Mediterranean mountains. Méditerranée 44:63-79. https://doi.org/10.4000/mediterran ee.7146

Hughes PD (2018) Little Ice Age glaciers and climate in the Mediterranean mountains: a new analysis. Geogr Res Lett 44:15-45. https://doi.org/10.18172/cig.3362

Hughes PD, Gibbard PL, Woodward JC (2004) Quaternary glaciation in the Atlas Mountains, North Africa. In: Ehlers J, Gibbard PL (eds) Quaternary Glaciation - Extent and Chronology, Vol 3: Asia, Latin America, Africa, Australia, Antarctica. Elsevier, Amsterdam, pp 255-260. https://doi.org/10.1016/S15710866(04)80131-3

Hughes PD, Fenton CR, Gibbard PL (2011) Quaternary glaciations of the Atlas Mountains, North Africa, 1st edn. In: Ehlers J, Gibbard PL, Hughes PD (eds) Quaternary glaciations - extent and chronology: a closer look. Developments in Quaternary Science 15. Elsevier, Amsterdam, pp 1,065-1,074. https://doi.org/10.1016/ B978-0-444-53447-7.00076-3

Hughes PD, Fink D, Rodés Á, Fenton CR, Fujioka T (2018) Timing of Pleistocene glaciations in the High Atlas, Morocco: new ${ }^{10} \mathrm{Be}$ and ${ }^{36} \mathrm{Cl}$ exposure ages. Quat Sci Rev 180:193-213. https://doi. org/10.1016/j.quascirev.2017.11.015

Hughes PD, Fletcher WJ, Bell BA, Braithwaite RJ, Cornelissen HL, Fink D, Rhoujjati A (2020) Late Pleistocene glaciers to presentday snowpatches: a review and research recommendations for the Marrakech High Atlas. Mediterr Geosci Rev 2:163-184. https:// doi.org/10.1007/s42990-020-00027-4

Ilahiane H (1999) The Berber Agdal institution: indigenous range management in the Atlas mountains. Ethnology 38:21-45

Ineson S, Scaife AA, Knight JR, Manners JC, Dunstone NJ, Gray LJ, Haigh JD (2011) Solar forcing of winter climate variability in the Northern Hemisphere. Nat Geosci 4:753-757. https://doi. org/10.1038/ngeo1282

Innes JB, Blackford JJ (2003) The ecology of Late Mesolithic woodland disturbances: model testing with fungal spore assemblage data. J Archaeol Sci 30:185-194. https://doi.org/10.1006/jasc. 2002.0832

Jarlan L, Khabba S, Er-Raki S et al (2015) Remote sensing of water resources in semi-arid Mediterranean areas: the joint international laboratory TREMA. Int J Remote Sens 36:4,879-4,917. https://doi.org/https://doi.org/10.1080/01431161.2015.1093198

Johnson PL, Billings WD (1962) The alpine vegetation of the Beartooth Plateau in relation to cryopedogenic processes and patterns. Ecol Monogr 32:105-135

Juggins S (2017) Rioja: analysis of Quaternary science data. https:// CRAN.R-project.org/package $=$ rioja

Jury SL, Rutherford RW, Rejdali M, Hassan R, El Atechi T (2008) The Vascular Flora of Oukaïmeden in the Moroccan High Atlas, 2nd Edition

Knippertz P, Christoph M, Speth P (2003) Long-term precipitation variability in Morocco and the link to the large-scale circulation in recent and future climates. Meteorol Atmos Phys 83:67-88. https://doi.org/10.1007/s00703-002-0561-y

Kuhlmann H, Meggers H, Freudenthal T, Wefer G (2004) The transition of the monsoonal and the $\mathrm{N}$ Atlantic climate system off $\mathrm{NW}$ Africa during the Holocene. Geophys Res Lett 31:1-4. https:// doi.org/10.1029/2004GL021267

Lacourse T, Gajewski K (2020) Current practices in building and reporting age-depth models. Quat Res 96:28-38. https://doi.org/ 10.1017/qua.2020.47

Legendre P, Gallagher ED (2001) Ecologically meaningful transformations for ordination of species data. Oecologia 129:271-280. https://doi.org/10.1007/s004420100716

Lüning S, Gałka M, Vahrenholt F (2017) Warming and cooling: the medieval climate anomaly in Africa and Arabia. Paleoceanography 32:1,219-1,235. https://doi.org/10.1002/2017PA003237 
Lüning S, Schulte L, Garcés-Pastor S, Danladi IB, Gałka M (2019) The medieval climate anomaly in the Mediterranean region. Paleoceanogr Paleoclimatol 34:1,625-1,649. https://doi.org/https:// doi.org/10.1029/2019PA003734

Mahdi M (2010) Patrimonialisation de la transhumance à l'Oukaïmeden ! In: Lerin F (ed) Pastoralisme méditerranéen: patrimoine culturel et paysager et développement durable. CIHEAM, Montpellier, pp 73-83

Marchane A, Tramblay Y, Hanich L, Ruelland D, Jarlan L (2017) Climate change impacts on surface water resources in the Rheraya catchment (High Atlas, Morocco). Hydrol Sci J 62:979-995. https://doi.org/10.1080/02626667.2017.1283042

Marty JT (2005) Effects of cattle grazing on diversity in ephemeral wetlands. Conserv Biol 19:1,626-1,632. https://doi.org/10. 1111/j.1523-1739.2005.00198.x

McCullough IM, Davis FW, Dingman JR et al (2016) High and dry: high elevations disproportionately exposed to regional climate change in Mediterranean-climate landscapes. Landsc Ecol 31:1,063-1,075. https://doi.org/10.1007/s10980-015-0318-x

McGregor HV, Dupont L, Stuut JBW, Kuhlmann H (2009) Vegetation change, goats, and religion: a 2000-year history of land use in southern Morocco. Quat Sci Rev 28:1,434-1,448. https://doi.org/ 10.1016/j.quascirev.2009.02.012

Medeanic S, Silva MB (2010) Indicative value of non-pollen palynomorphs (NPPs) and palynofacies for palaeoreconstructions: Holocene Peat, Brazil. Int J Coal Geol 84:248-257. https://doi. org/10.1016/j.coal.2010.08.015

Moberg A, Sonechkin DM, Holmgren K, Datsenko MH, Karlén W (2005) Highly variable Northern Hemisphere temperatures reconstructed from low- and high-resolution proxy data. Nature 433:613-617. https://doi.org/10.1038/nature03265

Moreno A, Pérez A, Frigola J et al (2012) The Medieval Climate Anomaly in the Iberian Peninsula reconstructed from marine and lake records. Quat Sci Rev 43:16-32. https://doi.org/10.1016/j. quascirev.2012.04.007

Munk A (1957) Danish pyrenomycetes. A preliminary flora. Dansk Botanisk Arkiv 17. Munksgaard, Kopenhagen

Nakagawa T, Brugiapaglia E, Digerfeldt G, Reille M, de Beaulieu J-L, Yasuda Y (1998) Dense-media separation as a more efficient pollen extraction method for use with organic sediment/deposit samples: comparison with the conventional method. Boreas 27:15-24. https://doi.org/10.1111/j.1502-3885.1998.tb00864.x

NASA/METI/AIST/Japan Spacesystems (2019) ASTER Global Digital Elevation Model V003. https://doi.org/10.5067/ASTER/ ASTGTM.003

Nieto C (2015) Tradición y modernidad en el valle de Oukaïmeden: Cambios en ritos y prácticas de transterminancia estacional. Complutum 25:191-207. https://doi.org/10.5209/rev_cmpl. 2014.v25.47347

Oksanen J, Blanchet FG, Friendly M et al (2017) vegan. Community Ecology Package. R package Version 2.4-3. https://CRAN.Rproject.org/package $=$ vegan

Ozenda P (1975) Sur les étages de la végétation dans les montagnes du bassin méditerranéen. Doc Cartogr Ecol 16:1-32

Pals JP, van Geel B, Delfos A (1980) Paleoecological studies in the Klokkeweel bog near Hoogkarspel (prov. of Noord-Holland). Rev Palaeobot Palynol 30:371-418. https://doi.org/10.1016/ 0034-6667(80)90020-2

Pepin N, Bradley RS, Dia HF et al (2015) Elevation-dependent warming in mountain regions of the world. Nat Clim Chang 5:424430. https://doi.org/10.1038/nclimate2563

Polo MJ, Pimentel R, Gascoin S, Notarnicola C (2020) Mountain hydrology in the Mediterranean region. In: Zribi M, Brocca L, Tramblay Y, Molle F (eds) Water Resources in the Mediterranean Region. Elsevier, Amsterdam, pp 51-75. https://doi.org/https:// doi.org/10.1016/B978-0-12-818086-0.00003-0
Puech S, Rascol J-P, Michel V, Andary C (1998) Cytogenetics and adaptation to increasingly arid environments: the example of Plantago albicans L. (Plantaginaceae). Biochem Syst Ecol 26:267-283. https://doi.org/10.1016/S0305-1978(97)00111-7

Quézel P (1957) Peuplement végétal des hautes montagnes de l'Afrique du nord. Editions Paul Lechevalier, Paris

R Core Team (2020) R: a language and environment for statistical computing. R Foundation for Statistical Computing, Vienna

Reille M (1976) Analyse pollinique de sédiments postglaciaires dans le Moyen Atlas et le Haut Atlas marocains: premiers résultats. Ecol Mediterr 2:155-170

Reille M (1992) Pollen et spores d'Europe et d'Afrique du Nord. Laboratoire de Botanique historique et Palynologie, Marseille

Reille M (1995) Pollen et spores d'Europe et d'Afrique du Nord, Supplément 1. Laboratoire de Botanique historique et Palynologie, Marseille

Reimer PJ, Austin WEN, Bard E et al (2020) The Intcal20 Northern Hemisphere radiocarbon age calibration curve (0-55 Cal kBP). Radiocarbon 64:725-757

Ruiz Zabata MB, Ruíz-Gálvez ML, Gil Garcia MJ (2010) Primeros datos polínicos procedentes del valle del río Irini (Oukaïmeden, Alto Atlas. Marruecos): aproximación al paisaje vegetal. Polen 20:41-60

Ruiz B, Gil MJ, Duque D (2014) Vegetation history in the Oukaïmeden Valley. Human action and the evolution of the landscape. Complutum 25:123-137. https://doi.org/10.5209/rev-CMPL. 2014.v25.47344

Saarinen T (1996) Biomass and production of two vascular plants in a boreal mesotrophic fen. Can J Bot 74:934-938

Shore JS, Bartley DD, Harkness DD (1995) Problems encountered with the ${ }^{14} \mathrm{C}$ dating of peat. Quat Sci Rev 14:373-383

Simonneaux V, Hanich L, Boulet G, Thomas S (2008) Modelling runoff in the Rheraya Catchment (High Atlas, Morocco) using the simple daily model GR4J. Trends over the last decades. In: Proceedings of the 13th IWRA World Water Congress. Montpellier, France, 1-4 September 2008

Sorre M (1924) Observations sur la végétation du Maroc. Ann Geogr $33: 257-266$

Steinman AD, Conklin J, Bohlen PJ, Uzarski DG (2003) Influence of cattle grazing and pasture land use on macroinvertebrate communities in freshwater wetlands. Wetlands 23:877-889. https:// doi.org/10.1672/0277-5212(2003)023[0877:IOCGAP]2.0.CO;2

Stockmarr J (1971) Tablets with spores used in absolute pollen analysis. Pollen Spores 13:615-621

Strack M, Waller MF, Waddington JM (2006) Sedge succession and peatland methane dynamics: a potential feedback to climate change. Ecosystems 9:278-287

Swingedouw D, Terray L, Cassou C, Voldoire A, Salas-Mélia D, Servonnat J (2011) Natural forcing of climate during the last millennium: fingerprint of solar variability. Clim Dyn 36:1,3491,364. https://doi.org/https://doi.org/10.1007/s00382-010-0803-5

Thiéblemont R, Matthes K, Omrani N-E, Kodera K, Hansen F (2015) Solar forcing synchronizes decadal North Atlantic climate variability. Nat Commun 6:8268. https://doi.org/10.1038/ncomm s9268

Tuel A, Chehbouni A, Eltahir EA (2020) Dynamics of seasonal snowpack over the High Atlas. J Hydrol 2020:125657. https://doi.org/ 10.1016/j.jhydrol.2020.125657

Tweel AW, Bohlen PJ (2008) Influence of soft rush (Juncus effusus) on phosphorus flux in grazed seasonal wetlands. Ecol Eng 33:242251. https://doi.org/10.1016/j.ecoleng.2008.05.003

Ubera JL, Galán C, Guerrero FH (1988) Palynological study of the genus Plantago in the iberian peninsula. Grana 27:1-15. https:// doi.org/10.1080/00173138809427728 
Väliranta M, Oinonen M, Seppä H, Korkonen S, Juutinen S, Tuittila $\mathrm{E}$ (2014) Unexpected problems in AMS ${ }^{14} \mathrm{C}$ dating of fen peat. Radiocarbon 56:95-108. https://doi.org/10.2458/56.16917

Van Geel B (1976) Fossil spores of Zygnemataceae in ditches of a prehistoric settlement in Hoogkarspel (The Netherlands). Rev Palaeobot Palynol 22:337-344

Van Geel B (1978) A palaeoecological study of Holocene peat bog sections in Germany and the Netherlands, based on the analysis of pollen, spores and macro-and microscopic remains of fungi, algae, cormophytes and animals. Rev Palaeobot Palynol 25(1):1-120

Van Geel B (2001) Non-Pollen Palynomorphs. In: Smol JP, Birks HJB, Last WM (eds) Tracking environmental change using lake sediments, vol. 3 Terrestrial, Algal, and Siliceous Indicators. Kluwer Academic Press, Dordrecht, pp 99-119

Van Geel B, Aptroot A (2006) Fossil ascomycetes in Quaternary deposits. Nova Hedwigia 82:313-329. https://doi.org/10.1127/00295035/2006/0082-0313

Van Geel B, Hallewas DP, Pals JP (1983) A Late Holocene deposit under the Westfriese Zeedijk near Enkhuizen (Prov. of NoordHolland, The Netherlands): palaeoecological and archaeological aspects. Rev Palaeobot Palynol 38:269-335. https://doi.org/10. 1016/0034-6667(83)90026-X

Van Geel B, Klink AG, Pals JP, Wiegers J (1986) An Upper Eemian lake deposit from Twente, eastern Netherlands. Rev Palaeobot Palynol 47:31-61. https://doi.org/10.1016/0034-6667(86) 90005-9

Van Geel B, Gelorini V, Lyaruu A et al (2011) Diversity and ecology of tropical African fungal spores from a 25,000-year palaeoenvironmental record in southeastern Kenya. Rev Palaeobot Palynol 164:174-190. https://doi.org/10.1016/j.revpalbo. 2011.01.002

Van Geel B, Brinkkemper O, Weeda EJ, Sevink J (2017) Formation, vegetation succession and acidification of a Mid-Holocene moorland pool in the western Netherlands. Neth J Geosci 96:17-27. https://doi.org/10.1017/njg.2016.1

Vieira G, Mora C, Faleh A (2017) New observations indicate the possible presence of permafrost in North Africa (Djebel Toubkal, High Atlas, Morocco). Cryosphere 11:1,691-1,705. https://doi. org/10.5194/tc-11-1691-2017

Wassenburg JA, Immenhauser A, Richter DK et al (2013) Moroccan speleothem and tree ring records suggest a variable positive state of the North Atlantic Oscillation during the Medieval Warm Period. Earth Planet Sci Lett 375:291-302. https://doi.org/10. 1016/j.eps1.2013.05.048

Zhao X, Dupont L, Cheddadi R et al (2019) Recent climatic and anthropogenic impacts on endemic species in southwestern Morocco. Quat Sci Rev 221:105889. https://doi.org/10.1016/j.quascirev. 2019.105889

Zkhiri W, Tramblay Y, Hanich L, Berjamy B (2017) Regional flood frequency analysis in the High Atlas mountainous catchments of Morocco. Nat Hazards 86:953-967. https://doi.org/10.1007/ s11069-016-2723-0

Publisher's Note Springer Nature remains neutral with regard to jurisdictional claims in published maps and institutional affiliations. 